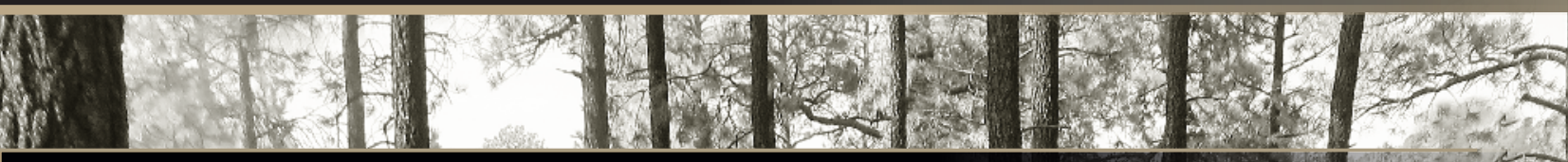

U.S. Geological Survey Wildland Fire Science Strategic Plan, 2021-26

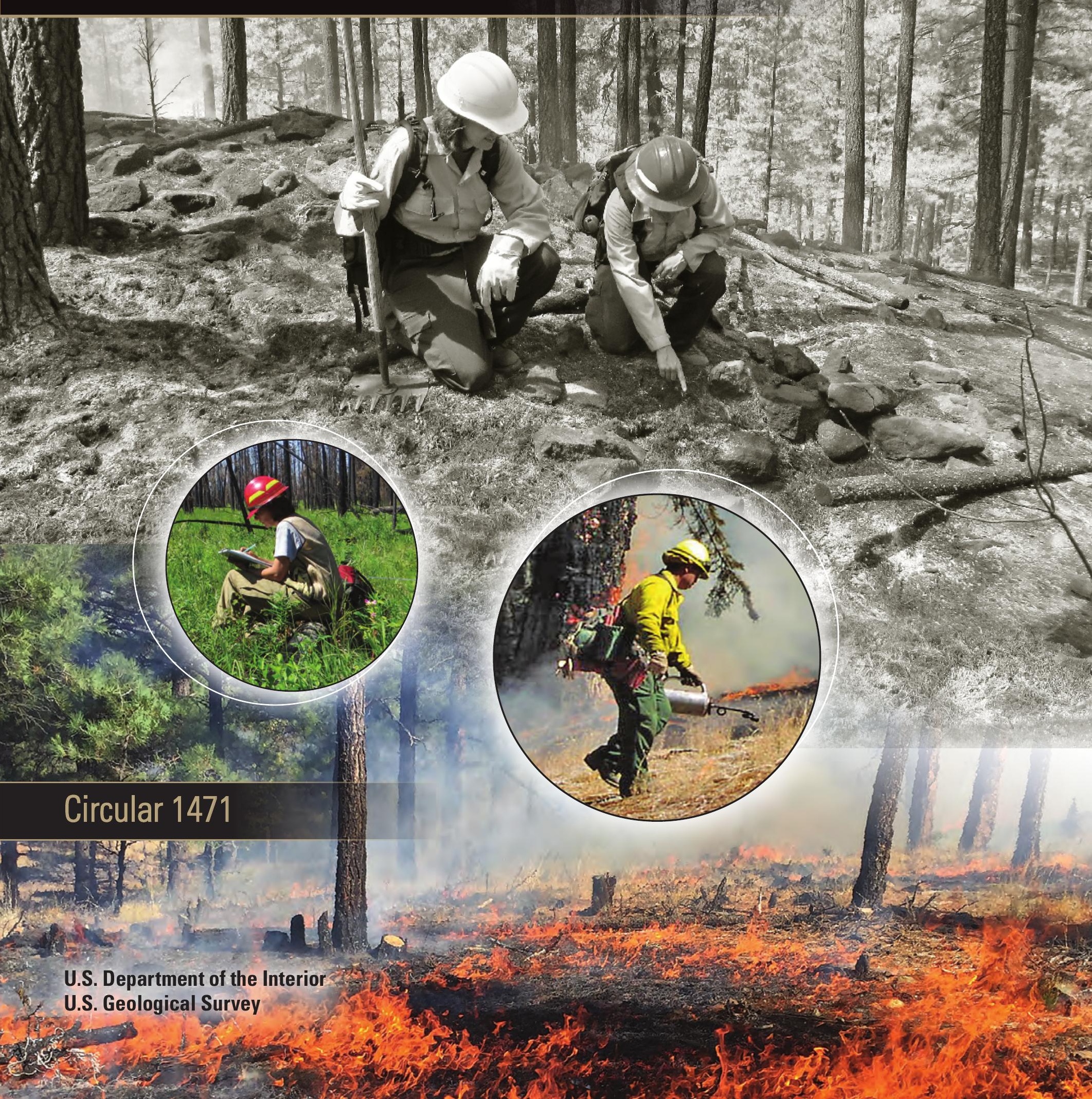


Cover: Black and white: Examining effects of a prescribed fire on archaeological sites,

Santa Fe National Forest, New Mexico. Photograph by Rachel Loehman, U.S. Geological Survey.

Top inset: Monitoring fire effects after the Funny River fire, 2015, Kenai Peninsula, Alaska.

Photograph by Rachel Loehman, U.S. Geological Survey.

Lower inset: Restoring fire to the land. Photograph by Eric Knapp, U.S. Forest Service.

Bottom: Prescribed fire, Santa Fe National Forest, New Mexico.

Photograph by Rachel Loehman, U.S. Geological Survey. 


\section{U.S. Geological Survey, Reston, Virginia: 2021}

For more information on the USGS - the Federal source for science about the Earth, its natural and living resources, natural hazards, and the environment-visit https://www.usgs.gov or call 1-888-ASK-USGS.

For an overview of USGS information products, including maps, imagery, and publications, visit https://store.usgs.gov/.

Any use of trade, firm, or product names is for descriptive purposes only and does not imply endorsement by the U.S. Government.

Although this information product, for the most part, is in the public domain, it also may contain copyrighted materials as noted in the text. Permission to reproduce copyrighted items must be secured from the copyright owner.

Suggested citation:

Steblein, P.F., Loehman, R.A., Miller, M.P., Holomuzki, J.R., Soileau, S.C., Brooks, M.L., Drane-Maury, M., Hamilton, H.M., Kean, J.W., Keeley, J.E., Mason, R.R., Jr., McKerrow, A., Meldrum, J.R., Molder, E.B., Murphy, S.F., Peterson, B., Plumlee, G.S., Shinneman, D.J., van Mantgem, P.J., and York, A., 2021, U.S. Geological Survey wildland fire science strategic plan, 2021-26: U.S. Geological Survey Circular 1471, 30 p., https://doi.org/10.3133/cir1471.

ISSN 2330-5703 (online) 


\section{Acknowledgments}

We thank our colleagues in the U.S. Geological Survey (USGS) and external partners, whose inputs clarified our vision and refined and enriched the USGS Wildland Fire Science Strategic Plan. A special thank you is due Anne Kinsinger (USGS, Ecosystems) for her leadership, input, and support on the development of this Strategic Plan. A cadre of reviewers provided invaluable suggestions, edits, and insights, including Sara Brown (U.S. Department of Agriculture Forest Service, Rocky Mountain Research Station), Sue Phillips (USGS, Forest and Rangeland Science Center), Tom Zimmerman (International Association of Wildland Fire), David Applegate (USGS,

Natural Hazards), Jonathan Godt (USGS, Landslide Hazards), Bradley Reed (USGS, Land Resources), Amy Symstad (USGS, Northern Prairie Wildlife Research Center), and Zhuoting Wu (USGS, Land Remote Sensing). We also gratefully acknowledge the contributions of the 40 individuals whose feedback, input, and ideas formed the basis for the stakeholder needs assessment in appendix 1 and contributed to strategies and perspectives detailed in the Strategic Plan.

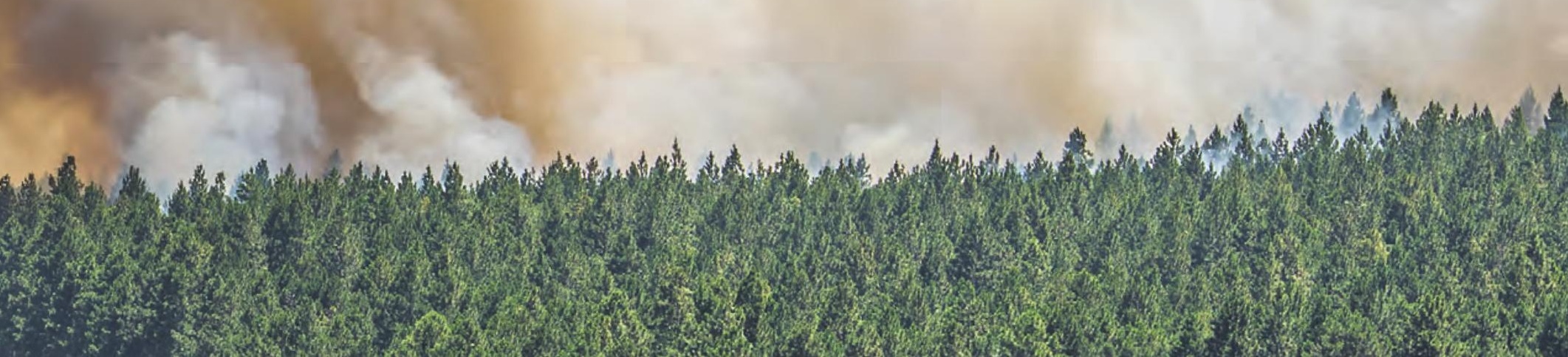




\section{Contents}

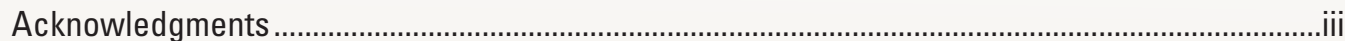

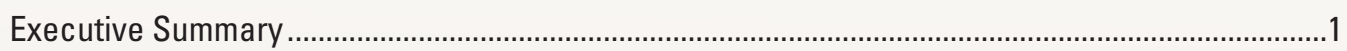

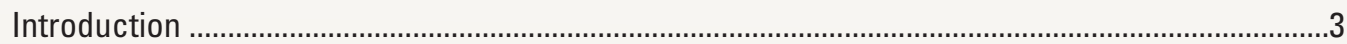

U.S. Geological Survey Strategic Priorities for Wildland Fire Science .........................................5

Priority 1: Produce State-of-the-Art, Actionable Fire Science ..............................................

Goal 1: Improve understanding of the impacts of climate change, changing fire regimes, and other ecosystem stressors and their synergistic interactions on fire behavior, fire risk, and fire effects in natural systems and human communities

Goal 2: Improve understanding of the relationships of fire and fire management to biodiversity conservation, ecosystem resilience, and post-fire recovery ...........8

Goal 3: Conduct science to help protect human lives, livelihoods, property, and infrastructure

Goal 4: Develop state-of-the-art tools and decision-support systems that enable land-, fire-, and emergency-managing bureaus and partners to obtain essential fire information

Priority 2: Engage Stakeholders in Science Production and Science Delivery ......................11

Goal 1: Actively and continually engage stakeholders throughout the fire-research life cycle by use of a science co-production approach

Goal 2: Apply effective science delivery practices to ensure that USGS fire science research, data, and tools are used by the people who need them

Priority 3: Effectively Communicate USGS Fire Science Capacity, Products, and

Information to a Broad Audience

Goal 1: Establish and maintain communication pathways for outreach to external audiences

Goal 2: Establish and maintain communication pathways for outreach to internal audiences

Priority 4: Enhance USGS Organizational Structure and Support for Fire Science.

Goal 1: Strengthen the USGS fire science organizational structure to enhance fire science coordination and prioritize critical fire science needs

Goal 2: Strengthen external partnerships to meet national fire science priorities and provide fire science leadership

Strategic Plan Implementation and Evaluation .......................................................................18

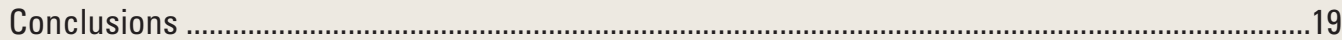

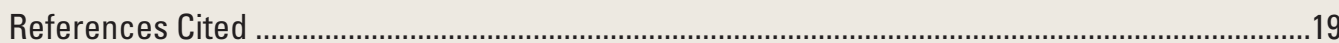

Appendix 1. Summary of Discussions of Fire Science With Stakeholders .................................21

\section{Figures}

1. Graphs showing annual acres burned by wildfires in the United States, 1983-2019, and Federal firefighting costs for suppression activities, 1985-2018

2. Map showing LANDFIRE Fire Regime Groups, which characterize the presumed historical fire regimes within landscapes based on interactions between vegetation dynamics, fire spread, fire effects, and spatial context 


\section{Conversion Factors}

U.S. customary units to International System of Units

\begin{tabular}{|c|c|c|}
\hline Multiply & By & To obtain \\
\hline \multicolumn{3}{|c|}{ Area } \\
\hline acre & 4,047 & square meter $\left(\mathrm{m}^{2}\right)$ \\
\hline acre & 0.4047 & hectare (ha) \\
\hline acre & 0.004047 & square kilometer $\left(\mathrm{km}^{2}\right)$ \\
\hline
\end{tabular}

\section{Abbreviations}

$\begin{array}{ll}\text { ARS } & \text { Agricultural Research Service } \\ \text { BAER } & \text { Burned Area Emergency Response } \\ \text { BIA } & \text { Bureau of Indian Affairs } \\ \text { BLM } & \text { Bureau of Land Management } \\ \text { CoP } & \text { Community of Practice } \\ \text { COSSA } & \text { USGS Council of Senior Scientist Advisors } \\ \text { DOI } & \text { U.S. Department of the Interior } \\ \text { EPA } & \text { U.S. Environmental Protection Agency } \\ \text { FEMA } & \text { Federal Emergency Management Agency } \\ \text { FLAME } & \text { Federal Land Assistance, Management and Enhancement } \\ \text { FSEN } & \text { Fire Science Exchange Network } \\ \text { FWS } & \text { U.S. Fish and Wildlife Service } \\ \text { GIS } & \text { geographic information system } \\ \text { JFSP } & \text { Joint Fire Science Program } \\ \text { LANDFIRE } & \text { Landscape Fire and Resource Management Planning Tools } \\ \text { MTBS } & \text { Monitoring Trends in Burn Severity } \\ \text { NASA } & \text { National Aeronautics and Space Administration } \\ \text { NIFC } & \text { National Interagency Fire Center } \\ \text { NIST } & \text { National Institute of Standards and Technology } \\ \text { NOAA } & \text { National Oceanic and Atmospheric Administration } \\ \text { NPS } & \text { National Park Service } \\ \text { NSF } & \text { National Science Foundation } \\ \text { OWF } & \text { Office of Wildland Fire } \\ \text { USACE } & \text { U.S. Army Corps of Engineers } \\ \text { USDA } & \text { U.S. Department of Agriculture } \\ \text { USFS } & \text { U.S. Forest Service } \\ \text { USGS } & \text { U.S. Geological Survey } \\ \end{array}$




\title{
U.S. Geological Survey Wildland Fire Science Strategic Plan, 2021-26
}

\author{
By Paul F. Steblein, ${ }^{1}$ Rachel A. Loehman, ${ }^{1}$ Mark P. Miller, ${ }^{1}$ Joseph R. Holomuzki, ${ }^{1}$ \\ Suzanna C. Soileau, ${ }^{1}$ Matthew L. Brooks, ${ }^{1}$ Mia Drane-Maury, ${ }^{1}$ Hannah M. Hamilton, ${ }^{1}$ \\ Jason W. Kean, ${ }^{1}$ Jon E. Keeley, ${ }^{1}$ Robert R. Mason, Jr., ${ }^{1}$ Alexa McKerrow, ${ }^{1}$ James R. Meldrum, ${ }^{1}$ \\ Edmund B. Molder, ${ }^{1}$ Sheila F. Murphy, ${ }^{1}$ Birgit Peterson, ${ }^{1}$ Geoffrey S. Plumlee, ${ }^{1}$ \\ Douglas J. Shinneman, ${ }^{1}$ Phillip J. van Mantgem, ${ }^{1}$ and Alison York ${ }^{2}$
}

\section{Executive Summary}

The U.S. Geological Survey's (USGS's) fire science mission is to produce and deliver the best available scientific information, tools, and products to support land and emergency management by individuals and organizations at all levels. The USGS wildland fire science program is built on over a century of cumulative research capacity. Today, USGS expertise in ecology, physics, chemistry, hydrology, geology, climatology, computer science and modeling, and geospatial technology and remote sensing is actively used to address challenges in wildland fire science and management across the Nation. USGS fire science is multidisciplinary in nature and emphasizes science support for the U.S. Department of the Interior administered lands and all of the Nation's non-forested ecosystems. The USGS also conducts science to support decisions by other Federal partners and Tribal, State, county, and local agencies. Key wildland fire science research includes dynamics of fires and fire effects in ecosystems, assessment of post-fire hazards and impacts, and development of longterm, high-quality national geospatial and remote sensing data systems and data products used in all phases of fire research and management. USGS wildland fire science provides information and tools that are fundamental to addressing the challenges and priorities of the National Cohesive Wildland Fire Management Strategy, the Nation's guiding framework for coordinating Federal, State, Tribal, and private efforts to restore and maintain landscapes, create fire-adapted communities, and improve fire response. Moreover, USGS fire scientists engage in research that addresses "fundamental problems with broad societal consequences" identified in a 2017 report by the USGS
Council of Senior Scientist Advisors. Close collaborations between USGS scientists and regional fire and land managers and a long-term investment in science production and delivery make the USGS a key resource for fire information at local and regional scales. The USGS also produces national scope datasets and research that are integral to national scale program management and policy development.

Fire is an essential natural process in fire-adapted and fire-dependent ecosystems across the Nation and plays a critical role in maintaining ecosystem processes and services. Wildland fire (any non-structure fire that occurs in vegetation or natural fuels, including wildfires and prescribed fires) can be used to restore historical forest structure and composition, preserve old growth, increase landscape heterogeneity, reduce hazardous fuels and future wildfire risk, and manage natural resources for the benefit of agriculture, ranching, forestry, and wildlife management. However, unplanned wildfires may be expensive to manage and can have massive impacts on human communities, causing economic disruption and the loss of homes, livelihoods, and lives. Anthropogenic climate changes and other environmental stressors have catalyzed a rapid escalation in wildfire area burned in the United States in the past three decades, resulting in significant impacts to ecosystems, health and safety risks to firefighters and citizens, expanding fire suppression costs, and loss of property and livelihoods. Fire and land managers are increasingly faced with emerging natural resource challenges that USGS science can address. These challenges offer opportunities for engagement of USGS scientists to provide current, objective, essential, and actionable fire science information and tools.

\footnotetext{
${ }^{1}$ U.S. Geological Survey.
} 
The USGS Wildland Fire Science Strategic Plan (hereafter, Strategic Plan) was developed by USGS fire scientists and executive leadership, and was informed by discussions with external stakeholders. The Strategic Plan is aligned with the needs of the fire science stakeholder community - fire, land, natural resource, and emergency managers from Federal, State, Tribal, and community organizations and members of the broad scientific community. The Strategic Plan also defines critical, core fire science capabilities for understanding fire-related and fireresponsive earth system processes and patterns and informing management decision making. The Strategic Plan is composed of four integrated priorities, each with associated goals and specific strategies for accomplishing the goals:

\section{Priority 1: Produce state-of-the-art, actionable fire} science.-Provide scientific analyses, data, and tools that inform current and future fire and land management decision making and promote understanding of fire-related and fireresponsive earth system processes and patterns.

\section{Priority 2: Engage stakeholders in science production} and science delivery.-Use a science co-production approach throughout the fire research life cycle to develop and maintain collaborations with stakeholders who are actively and continually engaged. This ensures that USGS research platforms and science products are relevant and useful for fire and land management decision making.

\section{Priority 3: Effectively communicate USGS fire science} capacity, products, and information to a broad audience.Strategically manage communications to effectively build awareness of and access to USGS wildland fire science and decision-support tools among key external and internal stakeholders.

Priority 4: Enhance USGS organizational structure and advance support for fire science.-Provide organizational structure and support that improves fire science production, coordination, and cooperation within the USGS and with external partners.

The priorities of this Strategic Plan define the USGS's commitment to producing and delivering cutting edge fire science, information, and decision-support tools. The USGS is a key producer of wildland fire science, with an investment that includes 100 to 200 ongoing fire-related projects, the production of numerous databases and tools, and the release of 70 to 90 publications per year from 2006 through 2017, which have been cited a cumulative 42,436 times as of 2018-an indication of the importance of USGS work to others.

Work by USGS scientists identifies impacts of changing climate, landscapes, and fire regimes on ecosystems; helps to protect human lives, livelihoods, property, and infrastructure; and provides essential fire information to land managing agencies and partners. The Strategic Plan further describes an organizational structure and support that improves fire science coordination and cooperation within and outside the USGS as a requisite for maintaining and expanding our science and commitments to stakeholders.

\section{Successful Strategic Planning for U.S. Geological Survey Fire Science}

- Production of high-quality, relevant, groundbreaking fire science research, data, tools, and technology that address needs of stakeholders and decision makers.

- Engagement of stakeholders to identify information needs and meet those needs efficiently.

- Science delivery and science communication to stakeholders, decision makers, and the scientific community.

- A fire science organization that effectively supports scientists in producing a broad portfolio of fire science-related products and science information, including databases, models, decision-support tools, and primary research on fire and ecosystem dynamics, that is used by stakeholders.

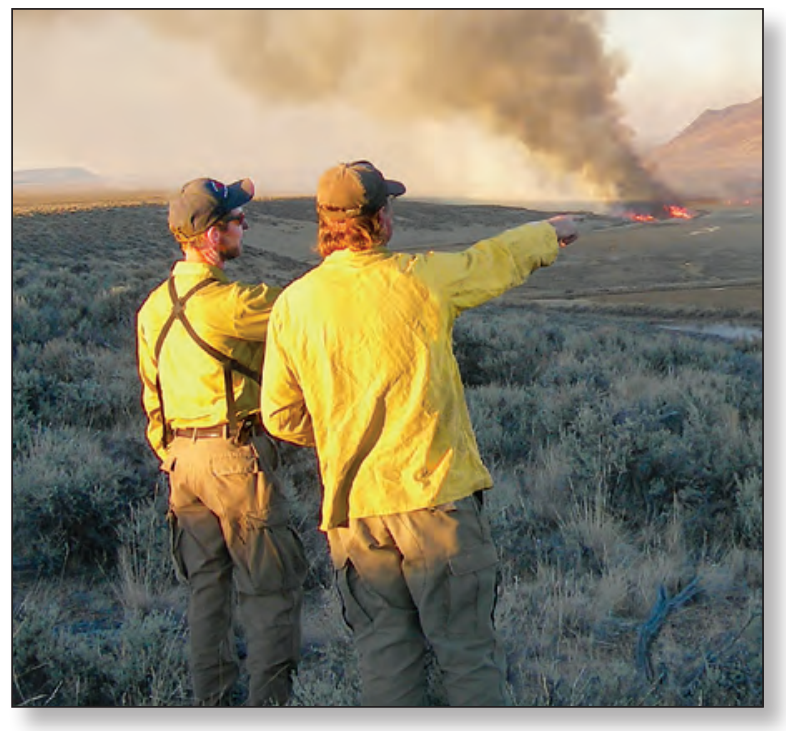

Prescribed fire in riparian habitat in sagebrush steppe ecosystem, Sheldon National Wildlife Refuge. Photograph by Paul Steblein, U.S. Geological Survey. 


\section{Introduction}

Fire is an essential natural process in fire-adapted and fire-dependent ecosystems around the globe. Fire plays a critical role in maintaining ecosystem processes and services including biological diversity and wildlife habitat, hydrological and nutrient cycling, biological productivity, ecosystem resilience, biological diversity, and wildlife habitat (Allen and others, 2002; Stephens and others, 2016; Pausas and Keeley, 2019). Wildland fire (any non-structure fire that occurs in vegetation or natural fuels, including wildfires and prescribed fires) can be used to manage forest, shrubland, and grassland structure and composition; preserve old growth forest; increase landscape heterogeneity; reduce fuel loads and mitigate future risk of severe wildfire; and manage natural resources for the benefit of agriculture, ranching, forestry, and wildlife management (Vogel and others, 2007; van Mantgem and others, 2011; Winter and others, 2012; North and others, 2015). However, unplanned wildfires may be expensive to manage and can have massive impacts on human communities, causing economic disruption and the loss of homes, livelihoods, and lives (Bowman and others, 2011). Anthropogenic climate change, land management, unplanned human ignitions, and environmental stressors have catalyzed a rapid escalation in wildfire area burned in the United States in the past three decades. These factors have been accompanied by significant increased health and safety risk to firefighters and citizens, an escalation in fire suppression costs, and loss of property and livelihoods (Schoennagel and others, 2017; Radeloff and others, 2018) (fig. 1). Changes in the timing, extent, frequency, and severity of wildfires as compared with historical patterns - occurring in the context of other ecosystem stressors such as drought, insect attacks, and weed invasions - can lead to increased tree mortality, loss of terrestrial carbon, negative impacts to wildlife habitat, increased soil erosion and postfire sedimentation, and changes in species and biome extent, distribution, and biodiversity (van Mantgem and others, 2009; Allen and others, 2010; Loehman and others, 2014; Coates and others, 2016; Clark and others, 2017; Sankey and others, 2017).

Fire and land managers are faced with emerging natural resource challenges that U.S. Geological Survey (USGS) science can — and does - address. These challenges offer opportunities for engagement of USGS scientists to provide the management community and policymakers with current, objective, essential, and actionable fire science information and tools. The USGS is an active partner in the U.S.

interagency fire science enterprise, which works across agency boundaries to address wildfire fire risk and behavior, dynamics of fires in ecosystems, and fire management. This enterprise includes cutting edge research conducted by Federal agencies,

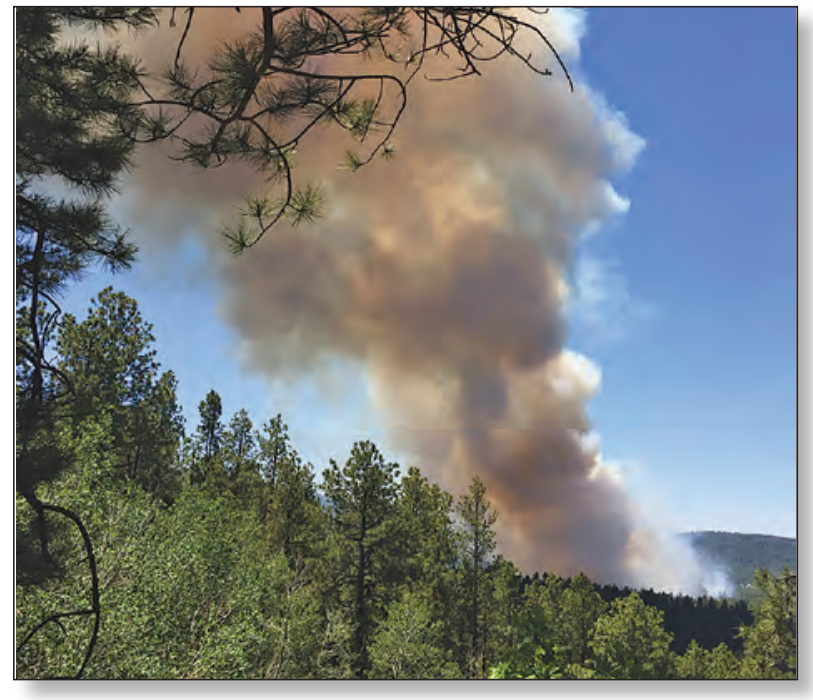

Smoke plume from the El Cajete fire, New Mexico, 2017. Photograph by Rachel Loehman, U.S. Geological Survey.

universities, and other organizations, partnerships and funding support provided by the Joint Fire Science Program, National Interagency Fire Center fire logistical fire management support, and leadership from the National Wildfire Coordinating Group enabling interoperable wildland fire operations among Federal, State, local, Tribal, and territorial partners.

USGS fire science emphasizes science support for the U.S. Department of the Interior (DOI) administered lands, which include 500 million acres of surface land - about one-fifth of the land area in the United States - managed by the Bureau of Land Management (BLM), the U.S. Fish and Wildlife Service (FWS), the National Park Service (NPS), the Bureau of Indian Affairs (BIA), and the Bureau of Reclamation. As the Nation's principal conservation agency, the DOI has the mission to protect America's treasures for future generations, provide access to our Nation's natural and cultural heritage, offer recreation opportunities, honor our trust responsibilities to American Indians and Alaska Natives and our responsibilities to island communities, conduct scientific research, provide wise stewardship of energy and mineral resources, foster sound use of land and water resources, and conserve and protect fish and wildlife.

Several DOI bureaus (BLM, FWS, NPS, BIA) and the U.S. Forest Service (USFS) are charged with managing fire on over 650 million acres of federally administered and Tribal lands, or 29 percent of the surface area of the Nation 

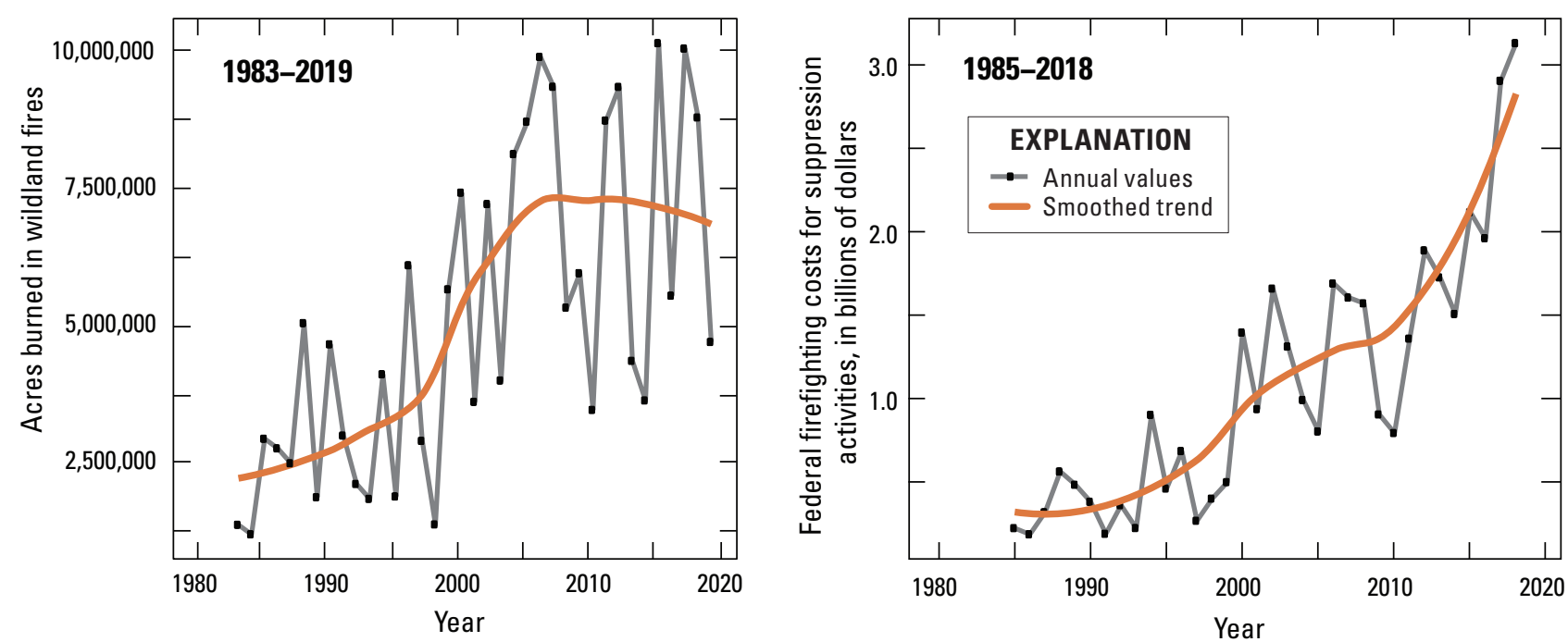

Figure 1. Annual acres burned by wildfires in the United States, 1983-2019 (left), and Federal firefighting costs for suppression activities, 1985-2018 (right). Notable are an overall increase in acres burned and a steep increase in the Federal costs to fight wildfires since the mid-1990s (National Interagency Fire Center, 2020).

(U.S. Geological Survey, 2020). A host of laws mandate this stewardship. ${ }^{3}$ The federal position has been to use a sciencebased approach to manage fuels to reduce the threats and negative consequences of uncharacteristic wildland fires (fires that are larger and more damaging) to natural and human communities. In 2009, the FLAME Act directed the DOI and U.S. Department of Agriculture (USDA) to develop a National Cohesive Wildland Fire Management Strategy (hereafter, Cohesive Strategy) to comprehensively address wildland fire management across all lands in the United States (Wildland Fire Leadership Council, 2014). The Cohesive Strategy vision for the 21 st century, to "safely and effectively extinguish fire, when needed; use fire where allowable; manage our natural resources; and as a Nation, live with wildland fire," embodies three critical, national goals:

Restore and maintain landscapes: Landscapes across all jurisdictions are resilient to fire related disturbances in accordance with management objectives;

Fire-adapted communities: Human populations and infrastructure can withstand a wildfire without loss of life and property;

Wildfire response: All jurisdictions participate in making and implementing safe, effective, efficient, risk-based wildfire management decisions.

${ }^{3}$ Forest Reserve Act (1891), Organic Act (1916), Snyder Act (1921), Wilderness Act (1964), National Wildlife Refuge System Administrative Act (1966), Endangered Species Act (1973), Federal Land Policy and Management Act (1976), Federal Land Assistance, Management and Enhancement (FLAME) Act (2009).
USGS wildland fire science provides information and tools that are fundamental to addressing the challenges and priorities of the Cohesive Strategy. The USGS has a strong foundation in fire science that is built on over a century of USGS cumulative research capacities. Close collaborations between USGS scientists and regional fire and land managers, production of national-scope research and datasets, and a long-term investment in science production and delivery make the USGS a key resource for fire information. Between 2006 and 2017 scientists from multiple disciplines across USGS published 970 wildland fire-related papers (Steblein and Miller, 2019) that fall within these categories. As of 2018 , these publications were cited 42,436 times, an indication of the importance of USGS work to others.

Today, USGS expertise in ecology, physics, chemistry, hydrology, geology, climatology, computer science and modeling, and geospatial technology and remote sensing is actively used to address a broad range of challenges in wildland fire science and management. Through its research and development efforts, the USGS contributes to fundamental fire science knowledge and wildland fire tools and applications in five broad categories:

1. Wildland fire behavior and fuels research, which enables prediction and mapping of fire risk, informs fuels treatment planning, and identifies the role of fireadapted invasive plants in amplifying wildfires; 


\section{Fire Science Definitions}

Fire behavior-The manner in which a fire reacts to the influences of fuel, weather, and topography.

Fire effects-The physical, biological, and ecological impacts of fire on the environment.

Fire management-All activities for the management of wildland fires to meet land management objectives. Fire management includes the entire scope of activities from planning, prevention, fuels or vegetation modification, prescribed fire, hazard mitigation, fire response, rehabilitation, monitoring and evaluation.

Fire regime - A description of the patterns of fire occurrences, frequency, size, severity, and effects in a given area or ecosystem.

Fire severity-The degree to which a site has been altered or disrupted by fire.

Fire suppression-Activities connected with control and fire-extinguishing operations, beginning with discovery and continuing until the fire is completely extinguished.

Fire weather-Weather conditions which influence fire ignition, behavior, and suppression.

Prescribed fire - A wildland fire originating from a planned ignition in accordance with applicable laws, policies, and regulations to meet specific objectives.

Wildfire-A wildland fire originating from an unplanned ignition, such as lightning, volcanoes, unauthorized and accidental human caused fires, and prescribed fires that are declared wildfires.

Wildland fire-Any non-structure fire that occurs in vegetation or natural fuels. Wildland fire includes prescribed fire and wildfire.

Wildland-urban interface-The line, area, or zone where structures and other human development meet or intermingle with undeveloped wildland or vegetation fuels.

Source: National Wildfire Coordinating Group (2018)
2. Fundamental fire ecology, which characterizes fire effects on flora, fauna, and ecosystems (terrestrial and aquatic), assesses potential for post-fire recovery and restoration, and provides critical foundational knowledge on fire's natural role in ecosystems;

3. Science related to current and future interactions of climate changes and wildfires, which quantifies impacts of anthropogenic climate change on fire behavior and fire effects, helps identify uncertainties in future ecosystem and fire trajectories, informs short- and long-term management and restoration plans, allows for prediction of future fire regimes and effects, and supports mitigation efforts for fire hazards and smoke emissions;

4. Science and tools related to post-fire risks of water contamination, flash floods, debris flows, and wind erosion, which provide critical risk and hazard assessments for ecological and human communities; and

5. Provision of remote sensing and geospatial data and products, which are integrated into the national interagency fire response and provide critical support before, during, and after wildfires and in the management decision-making process.

\section{U.S. Geological Survey Strategic Priorities for Wildland Fire Science}

The USGS Wildland Fire Science Strategic Plan (hereafter, Strategic Plan) was developed with input and feedback from the USGS fire science Community of Practice (hereafter, CoP), USGS scientists with expertise in wildland fire science and related topics, and the USGS executive leadership. The Strategic Plan is aligned with needs of the wildland fire science stakeholder community - fire, land, natural resource, and emergency managers from Federal, State, Tribal, and community organizations and members of the broad scientific community - as informed by consultations with stakeholders (appendix 1). Four integrated priorities, goals associated with each priority, and specific strategies to accomplish the goals were identified in the planning process and form the basis for the Strategic Plan:

Priority 1: Produce state-of-the-art, actionable fire science-Provide scientific analyses, data, and tools that inform current and future fire and land management decision 
making and promote understanding of fire-related and fireresponsive earth system processes and patterns.

Priority 2: Engage stakeholders in science production and science delivery-Use a science co-production approach throughout the fire research life cycle to develop and maintain collaborations with stakeholders who are actively and continually engaged. This ensures that USGS research platforms and science products are relevant and useful for fire and land management decision making.

Priority 3: Effectively communicate USGS fire science capacity, products, and information to a broad audienceStrategically manage communications to effectively build awareness of and access to USGS wildland fire science among key external and internal stakeholders.

Priority 4: Enhance USGS organizational structure and advance support for fire science-Provide organizational structure and support that improves fire science production, coordination, and cooperation within the USGS and with external partners.

\section{Priority 1: Produce State-of-the-Art, Actionable Fire Science}

USGS scientists produce key science related to fire dynamics in ecosystems, predictions of fire-related hazards and risks, assessments of post-fire effects on ecosystems and plant and animal species, and development of long-term, highquality national geospatial and remote sensing data systems and data products used in all phases of fire research and management. USGS wildland fire science and this Strategic Plan seek to meet the targets of two strategic documents. First, scientists provide information and tools that are fundamental to addressing the challenges and priorities of the Cohesive Strategy. Second, USGS fire scientists engage in research that addresses "fundamental problems with broad societal consequences" identified in the 2017 USGS Council of Senior Scientist Advisors (COSSA) report (Jenni and others, 2017) - particularly, natural resource security, societal risk from existing and emerging threats, and anticipatory science for changing landscapes. Key fire science goals and specific strategies to accomplish the goals are described below.

\section{U.S. Geological Survey Mission and Overarching Organization}

The U.S. Geological Survey (USGS) is a scientific agency that is housed within the U.S. Department of the Interior (DOI). Its primary mission is conducting science; in contrast to other DOI bureaus, it has no regulatory authority and does not manage any major Federal land areas. Created by an act of Congress in 1879 , the USGS has evolved over the ensuing 125 years, matching its talent and knowledge to the progress of science and technology. The USGS serves the Nation by providing reliable scientific information to describe and understand the Earth; minimize loss of life and property from natural disasters; manage water, biological, energy, and mineral resources; and enhance and protect our quality of life. Scientific activities are conducted under interdisciplinary mission areas focused on ecosystems, surveys and mapping, energy and mineral assessments, environmental health, land change, water resources, and natural hazards.

To foster multidisciplinary science, the USGS organized itself geographically into regional offices in 2000. These offices are led by Regional Directors with supervisory and oversight responsibility for the various science centers within their geographic region-regardless of the topical discipline.

Scientists, technicians, and support staff of the USGS are located in nearly 300 offices across the United States. The majority of these offices are organized under the Regional Directors; however, there are some large national centers that report directly to mission area Associate Directors. In 2019, the USGS's regional boundaries were adjusted to align with one or more of the $12 \mathrm{DOI}$ regions. Each mission area is led by an Associate Director and a team of Program Coordinators responsible for the strategic planning and budget formulation for the work that is ultimately carried out through the science centers across the organization. USGS headquarters and mission area Associate Directors are located in Reston, Virginia. 
Goal 1: Improve understanding of the impacts of climate change, changing fire regimes, and other ecosystem stressors and their synergistic interactions on fire behavior, fire risk, and fire effects in natural systems and human communities

Climate change contributes to the trends toward fires that occur more frequently, burn larger areas, burn at higher severity, and burn for longer than in the past. Changes in fire regimes affect ecosystem processes and services, delay or destroy the ability of systems to recover after fires, and can impact human health. Other disturbance factors such as invasive species, insect infestations, and disease outbreaks co-occur with climate changes to amplify fire impacts and further stress ecosystems. Land use and management actions taken to achieve goals of U.S. national parks, refuges, other public lands, and Tribes (for example, fire suppression activities, silviculture, and grazing) also affect fire regimes and can increase ecosystem vulnerability and influence viability of future management actions. Strategies to address science needs related to linked climate, fire, and ecosystem dynamics include the following:

Strategy 1: Develop a better understanding of changing fire regimes. Shifting climate and land use patterns have altered fire frequency, intensity, size, pattern, seasonality, and severity (that is, fire regimes) in many ecosystems, with impacts on natural and cultural resources, post-fire recovery, and resilience. The USGS provides science that enhances our understanding of potential future fire regimes and ecosystem impacts, which is critical for fire and land management.

Strategy 2: Characterize the impacts of disturbance interactions and synergies on species, landscapes, and ecosystems. Co-occurrence of climate stress and other disturbances can result in highly visible, rapidly occurring, and persistent changes in landscapes and ecosystems. USGS fire science focuses on identifying, quantifying, and forecasting drivers of ecological change and ecosystem impacts, thus addressing critical knowledge gaps and uncertainties in land management.

Strategy 3: Increase capabilities for assessing and predicting burn severity. Burn severity is complex and influenced by a variety of drivers including climate changes, land cover, disturbance and management history, topography, and fire weather. The severity of fires affects ecosystem functioning (for example, aboveground and belowground productivity, energy flow, and nutrient cycling), ecosystem

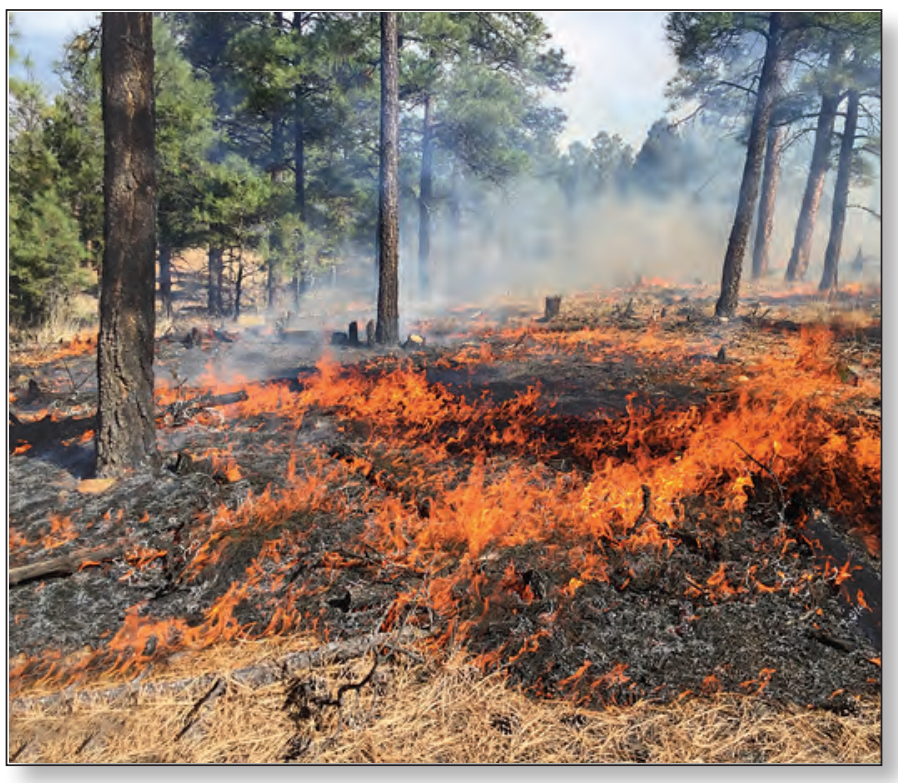

Prescribed fires are used by land managers to restore ponderosa pine forests to more resilient conditions. We are fortunate to be able to occasionally participate in such burns because we are colocated with land managers. Photograph by U.S. Geological Survey.

services (for example, wildlife habitat, water supply, wood products, livestock forage, and recreation), post-fire vegetation recovery, and post-fire hazards (for example, debris flows, flash floods, and water quality impacts). An understanding of the drivers and landscape patterns of burn severity is critical for anticipating and quantifying landscape change and managing public lands and resources.

Strategy 4: Use complex modeling approaches to forecast impacts of future climate and fire regimes on ecosystems. The need for a better understanding of the impacts of climate changes on wildfires and ecosystems is reaching new levels of urgency, as managers are challenged to mitigate increasingly severe ecosystem impacts (Loehman and others, 2020). Ecological models offer a means to anticipate these impacts, but prediction of future conditions is dependent on the ability of models to represent multiscale interactions, feedbacks, and nonlinear effects to realistically represent complex and emergent ecosystem dynamics. The USGS expands these frontiers of knowledge to develop necessarily complex models to increase our ability to develop ecologically informed strategies for management and conservation. 
Goal 2: Improve understanding of the relationships of fire and fire management to biodiversity conservation, ecosystem resilience, and post-fire recovery

The various mechanisms that affect wildland fire science and management are complex and are inextricably linked to land use and conservation management. Science strategies that address these relationships include the following:

Strategy 1: Identify ways to better assess landscapescale fuel characteristics and evaluate the role of wildland fuels in driving anomalous fire events in ecosystems. Land use practices (for example, fire suppression, grazing, and urbanization of wildlands) and unplanned human ignitions influence fuel and fire characteristics, and thus alter fire regimes (Butsic and others, 2015). Developing comprehensive fuels assessments_-including remote mapping of flammable, invasive species and characterization of surface and canopy fuels - will aid in the detection of fire risk and ecosystem vulnerabilities, can be used to assess fuel treatment effectiveness and inform relationships among invasive species, fire risk, and land uses such as energy corridors, transportation networks, communication infrastructure, and grazing.

Strategy 2: Expand understanding of ignition sources in landscapes. Characterizing the relationships among ignition sources, fire activity, and climate variability across fire regions and biomes will inform fire prevention programs, fire risk predictions, and fire management.

Strategy 3: Conduct science that addresses wildfire impacts on biodiversity and conservation. Science critical for informing management actions includes comprehensive research on the role of fires in ecosystems and various fire effects on biota, and the potential for mitigation of unwanted impacts via management activities.

Strategy 4: Relate assessments of burn severity to fire management and whole-ecosystem recovery and restoration. Developing post-fire assessments of burn characteristics, including fire severity and fire effects on biological, physical, chemical, and hydrologic processes, is important for understanding the spatial and temporal scales and magnitude of fire-driven changes, identifying appropriate and necessary emergency responses, and for developing strategies for mitigation and recovery activities within and associated with burned areas.

Strategy 5: The USGS provides critical information on how fuels and fire weather affect species and ecosystems as detected before, during, and after prescribed fires and species and ecosystem effects. This science informs management actions related to efficient and effective use of fire to control invasive species, restore forest structure, restore grasslands, and provide habitat for fire-adapted species.

\section{Goal 3: Conduct science to help protect human lives, livelihoods, property, and infrastructure}

Nationwide, humans play a major role in increasing wildfire activity (Syphard and others, 2017). Over the past few decades unplanned, human-caused wildfires accounted for 84 percent of all wildfires, tripled the length of the fire season, dominated an area seven times greater than that affected by lightning fires, and were responsible for nearly one-half of the extent of burned area across the United States (Balch and others, 2017). Wildfires can damage property and critical infrastructure such as energy corridors, water supplies, and transportation networks. Many parts of the western United States are experiencing population growth, with expansion into wildlands that increasingly exposes communities to wildland fire (Liu and others, 2015). Each locality and fire are unique, requiring community-level planning and preparedness for fire adaptation. USGS science strategies related to understanding fire impacts on communities include the following:

Strategy 1: Support efforts to develop fire-adapted communities. USGS science helps to inform and encourage the development of guidelines for fire-adapted communities; for example, through studies on how the environment in and around the wildland-urban interface impacts the potential for infrastructure losses from fire, and through research on how communities successfully adapt to wildland fire and its impacts.

Strategy 2: Help prevent catastrophic fires at the wildlandurban interface. USGS scientists are actively engaged in understanding the history of ignition sources within wildlandurban interfaces and the susceptibility of human communities and structures to wildfire damages. This work helps to explain or predict how past, present, and potential future wildfire patterns affect society and can be used to reduce risk to communities.

Strategy 3: Understand the human health and safety impacts of wildfire. The USGS collaborates with with partners (for example, USFS, U.S. Environmental Protection Agency, Centers for Disease Control and Prevention, National Oceanic and Atmospheric Administration, U.S. Department of Energy) to better characterize human hazards (for example, diminished water and air quality from smoke, ash, and wind-blown particles) from fires on DOI administered and neighboring lands.

Strategy 4: Preserve the integrity of traditional lands and resources. USGS scientists prioritize collaborations with Tribes, agencies, and others concerned with preserving and protecting the important ecological and cultural properties that define traditional landscapes. These actions help prevent damage to cultural sites and artifacts, protect subsistence and medicinal resources, respect data sovereignty of Tribes, and incorporate traditional fire and land management practices into contemporary applications. 
Goal 4: Develop state-of-the-art tools and decision-support systems that enable land-, fire-, and emergency-managing bureaus and partners to obtain essential fire information

The USGS collaborates with the USFS; Joint Fire Science Program; National Aeronautics and Space Administration (NASA); National Oceanic and Atmospheric Administration; U.S. Departments of Defense and Energy; universities; other science organizations; and fire, land, and resource managers to produce information, data, and tools that are useful to communities, Tribes, States, and Federal agencies. Stakeholder needs for data, tools, and decision support evolve rapidly with each new fire season and with technological expansion; thus, the USGS actively engages in research aimed at delivering the right information at the right time in a useful form, into the hands of people making decisions. Strategies to expand and develop USGS fire science research include the following:

Strategy 1: Maintain and expand geospatial data and support for wildfire incidents and planning. Currently, the USGS maintains the National Land Imaging Program (https://www.usgs.gov/land-resources/national-land-imagingprogram), a primary source of geospatial land imaging data and derived models that are used for fire science. The USGS operates the Landsat series of Earth observation satellites, manages the long-term, science quality Landsat data archive with NASA, and provides derived Landsat science products (for example, burned area extent and burn probability) from Landsat analysisready data. The USGS is a key partner in the Monitoring Trends in Burn Severity (MTBS) program (https://www.mtbs.gov/), an interagency program that consistently maps the severity and extent of large fires across all lands of the United States using remote sensing data from 1984 to the present. The USGS is also a partner in the Landscape Fire and Resource Management Planning Tools (LANDFIRE) program (https://www.landfire.gov/), a shared program between the USFS and the DOI that provides remote sensing derived, national-scale geospatial products to support cross-boundary modeling, planning, management, and operations. For example, LANDFIRE maps a Fire Regime Groups which indicate historical wildfire patterns (fig. 2). Processing of classified satellite data for wildfire applications, coordinated by the USGS National Civil Applications Center, enables enhanced

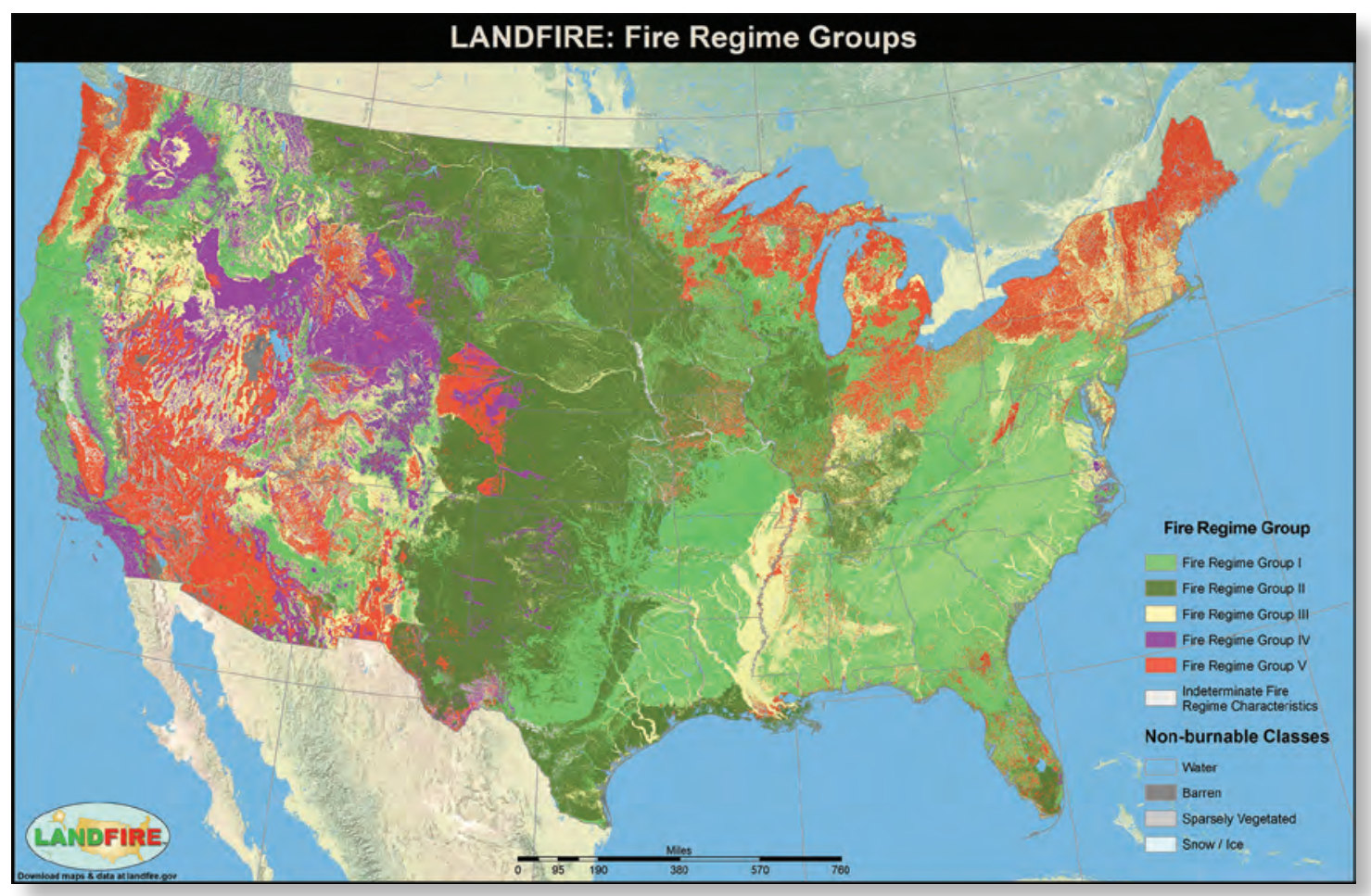

Figure 2. LANDFIRE Fire Regime Groups, which characterize the presumed historical fire regimes within landscapes based on interactions between vegetation dynamics, fire spread, fire effects, and spatial context. These data are used in landscape assessments and for management planning. Fire Regime Groups are defined as follows: Fire Regime Group I-less than or equal to 35-year fire return interval, low and mixed severity; Fire Regime Group II-less than or equal to 35-year fire return interval, replacement severity; Fire Regime Group III-35- to 200-year fire return interval, low and mixed severity; Fire Regime Group IV—35- to 200-year fire return interval, replacement severity; Fire Regime Group V—greater than 200-year fire return interval, any severity. 
fire detection and perimeter mapping in some regions. Expanded geospatial data and support needs include development of new sensors and platforms for improved fire detection and mapping, use of artificial intelligence and machine learning techniques to provide rapid, real-time fire information, and development of advanced, integrated models that link key processes related to fire risk, fire behavior, and fire effects to land, water, flora, fauna, and human communities.

Strategy 2: Improve predictive capability for post-fire flash flood and water quality hazards, including adaptation strategies for water providers. The USGS implements key investigations that include dynamics of post-fire sediment mobilization and transport into aquatic systems, nutrient and contaminant transport into aquatic systems (that is, water quality impacts), post-fire flooding and changes in water infiltration and aquifer recharge owing to changes in soil properties, and the long-term effectiveness of natural ecosystem recovery and managed revegetation efforts in mitigating water-related hazards.

\section{Successful Outcomes From U.S. Geological Survey (USGS) Fire Science}

- The USGS conducts cutting-edge research to produce critical insights, information, data, and tools for managing ecosystems and mitigating risk to human communities and resources.

- USGS wildland fire science informs National Cohesive Wildland Fire Management Strategy goals of restoring and maintaining resilient landscapes, promoting fire-adapted communities, and facilitating a safe, effective wildfire response that protects human lives.

- Partners and stakeholders use USGS fire science products, information, and tools to inform and enhance management decision making.

- USGS science is conducted in a collaborative manner across disciplines and with partners to better harness the diverse capabilities that exist within the USGS.

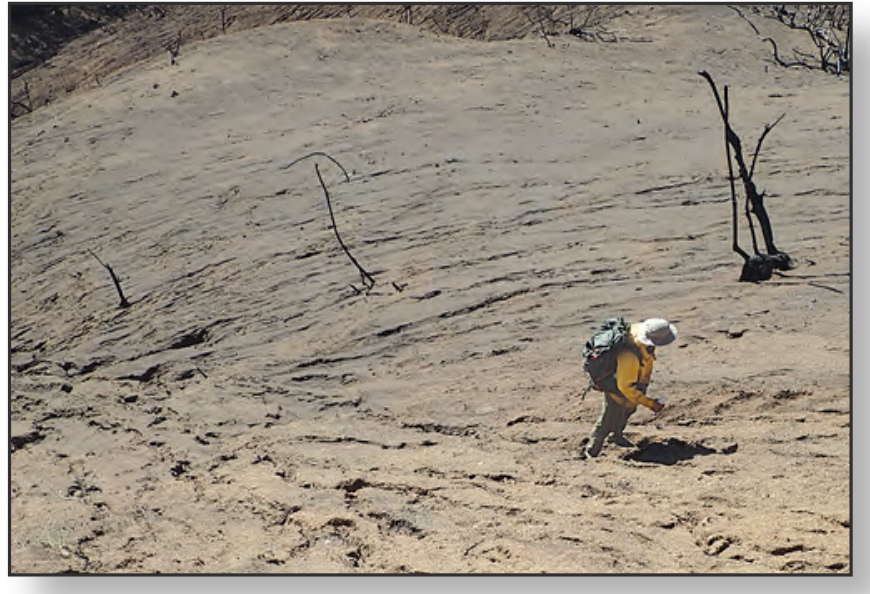

U.S. Geological Survey (USGS) scientist monitors a debris-flow event following the Thomas fire, Montecito, California, 2018. Photograph by Jason Kean, USGS.

Strategy 3: Conduct in-depth debris-flow hazard and risk assessments. Applied research aids in modeling the potential for post-fire debris flows (fast-moving landslides), as influenced by precipitation events and landscape characteristics. Monitoring post-fire recovery through repeat assessments provides input into debris-flow probability models that are used to assess community vulnerability. Debris-flow hazard assessments support DOI, USFS, and State Burned Area Emergency Response (BAER) teams; State and local emergency management; and the National Weather Service in the delivery of debris-flow alerts.

Strategy 4: Expand biomass and carbon modeling for wildfires. Assessments of recent greenhouse gas emissions from wildfires and modeled estimates of future potential wildfire activity, biomass consumption, and greenhouse gas emissions under a range of climate, land use and land cover change, and fire-management scenarios identify important fire feedbacks to the global climate system and provide critical information for land management and policy.

Strategy 5: Remain actively involved in development of next-generation science and technology for fire mapping and modeling. The USGS supports ongoing research and development in the following areas: improved models of fire behavior and fire effects, particularly in non-forest ecosystems; smoke emissions and dispersion modeling for non-forest ecosystems and for emissions that are critically important to human and environmental health (for example, asbestos, metals, ash, and complex organic compounds); and use of cloud computing, advanced machine learning, and new sensor networks and platforms to enhance fire mapping, monitoring, and prediction capabilities. 


\section{Priority 2: Engage Stakeholders in Science Production and Science Delivery}

The USGS identifies a diverse fire science stakeholder community that includes fire, land, natural resource, and emergency managers from Federal, State, Tribal, and community organizations and members of the broad scientific community. Stakeholders have expressed needs for specific information and science-based tools required to address emerging wildland fire challenges (for example, anticipating and addressing the impacts of climate changes on vegetation, fuels, and fire behavior and effects, including how to manage fires in this context; appendix 1). These needs reflect the complexity of wildland fires, the imminent but uncertain impacts of climate changes on fire regimes and ecosystems, and the increasing human footprint on wildlands, all of which make it difficult - but critical - to predict potential wildfire risks and understand the ways in which atypical wildfires are fundamentally altering our natural environments and the goods and services they provide. To address these growing needs, the USGS is committed to working with partners to enhance the national wildland fire research capacity and to provide stakeholders with critical scientific analysis, data, and tools that inform management decisions. Goals and strategies essential for maintaining effective science production and delivery practices and ensuring that fire science research, data, and tools are accessible and relevant to stakeholders are described below.

\section{Goal 1: Actively and continually engage stakeholders throughout the fire-research life cycle by use of a science co-production approach}

It is essential that USGS scientists work with stakeholders to identify science and information gaps, develop approaches for filling those gaps, and determine effective mechanisms for science delivery and application throughout the duration of research endeavors. Appropriate follow through with stakeholders who are using USGS science is also critical to help assess relevance of produced science, to support science application, and to identify further research or information transfer needs. Ideally, this co-production approach ensures that resulting information and tools are of the highest value to the user community. However, fire science stakeholder engagement can be substantially curtailed by short-duration funding cycles

\section{USGS and the Joint Fire Science Program's Fire Science Exchange Network (FSEN): Connecting Scientists and Stakeholders}

The U.S. Geological Survey (USGS) plays an active role in governance of the Joint Fire Science Program (JFSP), which is jointly funded by the U.S. Departments of Agriculture and the Interior to support scientific research on wildland fires and distribute results to help policymakers, fire managers and practitioners make sound decisions. The Joint Fire Science Program's Fire Science Exchange Network (FSEN; https://www.firescience.gov/JFSP_exchanges.cfm) provides a critical function by facilitating science delivery and stakeholder engagement and developing collaborations among fire managers, practitioners, and scientists. The FSEN is a national collaboration of 15 regional fire science exchanges located throughout the United States, with the stated goal to "... accelerate the awareness, understanding, adoption, and implementation of readily available wildland fire science information." Regional fire science exchanges represent valuable boundary-spanning organizations that can partner with scientists and science centers to promote science delivery by coordinating field trips, tours, demonstrations, workshops, and webinars or other training events. Furthermore, they maintain regionally focused expertise to help local managers and practitioners digest and incorporate the most relevant fire science information for the specific lands that they manage. The USGS is committed to supporting production of actionable science and effective science delivery through partnership with the JFSP FSEN.

that restrict the duration of research projects (that is, timelines that are too brief to provide much meaningful information to land managers and decision makers), severely limit opportunities for science application and technology transfer, and make it harder to build the trust and teamwork needed for a co-production approach. Strategies for promoting successful stakeholder engagement include the following: 
Strategy 1: Engage stakeholders at all stages of research. This ensures science needs are identified, studies are well designed to meet those needs, and information and products are delivered in an effective and timely way.

Strategy 2: Work with Indigenous peoples in co-production of fire science. The USGS is committed to working with Indigenous peoples to incorporate traditional knowledge, research interests, and science needs into collaborative fire science priorities; to acknowledge the importance of Indigenous fire knowledge and practices for land stewardship; and to promote collaborative fire science on Tribal lands and for Tribal concerns and interests.

Strategy 3: Use multipartner and multidisciplinary approaches and solutions. These are critical for addressing increasingly demanding, dynamic, and complex wildland fire science issues.

Strategy 4: Integrate disciplines outside of traditional wildland fire science to include anthropology, geography, biology, socioeconomics, physics, and chemistry, among others.

Strategy 5: Include international partners and perspectives whenever possible, especially from parts of the world faced with similar, pressing wildland fire issues (for example, Africa, Australia, Canada, Siberia, South America, southern Europe), and in places where USGS fire science can be helpful in local decision making and resource management.

Strategy 6: Partner with boundary-spanning organizations such as the Joint Fire Science Program's Fire Science Exchange Network. Boundary-spanning organizations bridge potential divides between scientists and nonscientists by creating tools and hosting events that facilitate collaboration and opportunities for engagement.

Strategy 7: Apply dedicated USGS fire science funding through research lines and projects to meet science needs identified through engagement with stakeholders.

\section{Goal 2: Apply effective science delivery practices to ensure that USGS fire science research, data, and tools are used by the people who need them}

The USGS places explicit value on science delivery (knowledge utilization, technology transfer, and innovation diffusion) as a vital component of the research project life cycle. As a scientific research agency with no management or regulatory mandates, the USGS has in the past been

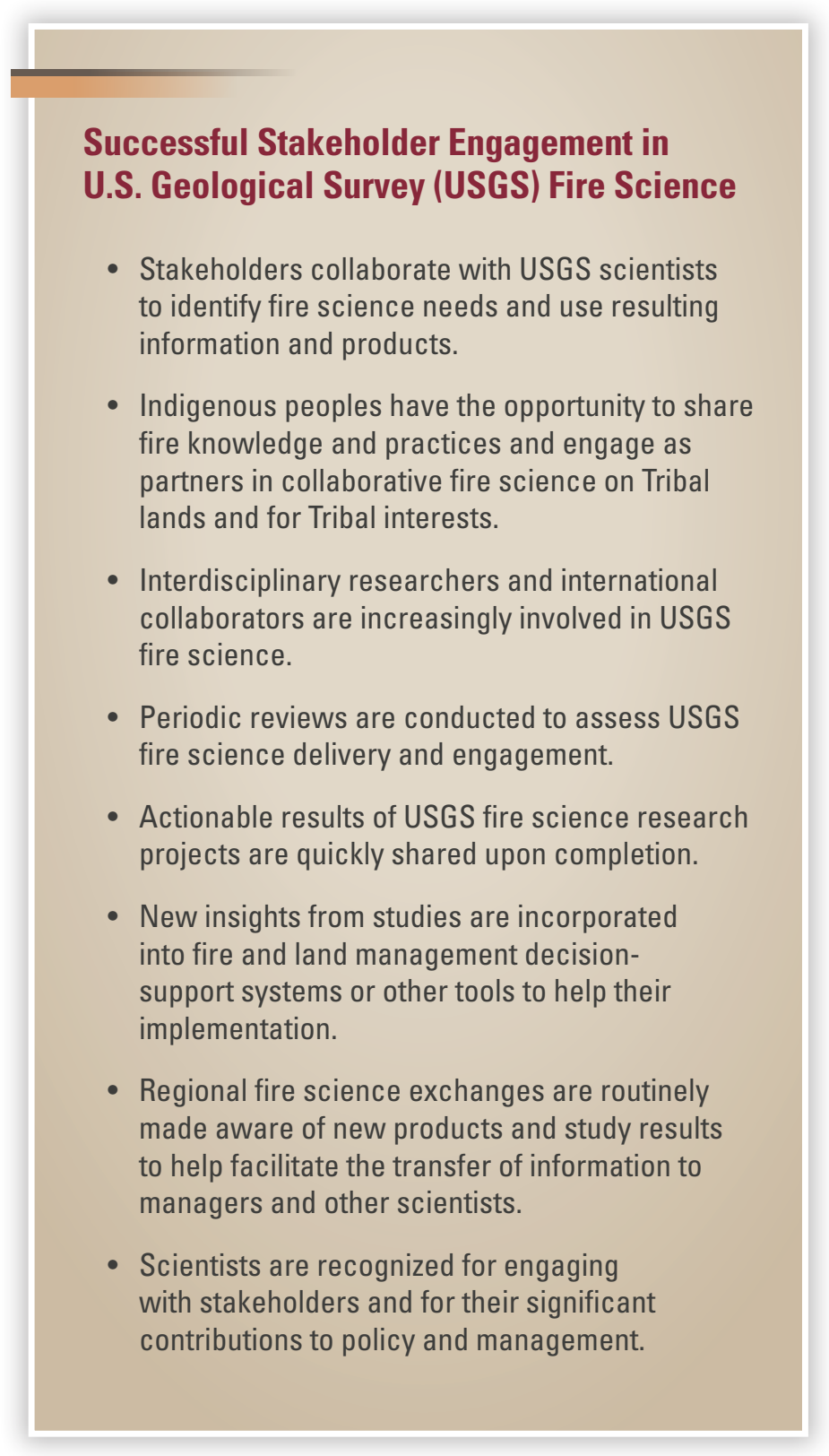

challenged to provide a bridge between the USGS scientists who develop new knowledge and the individuals and organizations who are best poised to make decisions using this information. The following science delivery strategies, designed for the fire science and management communities (partially adapted from Wright, 2010), can help ensure that new fire science knowledge is received by potential users in a rapid and effective manner: 
Strategy 1: Target science delivery to innovators and early adopters (opinion leaders who can jump-start diffusion and use of information among their peers) and individuals in positions responsible for research use and communication.

Strategy 2: Develop products in formats and using language that managers and decision makers can easily digest.

Strategy 3: Recognize the importance of informal communication as a tool for establishing relationships with stakeholders.

Strategy 4: Ensure objectivity in both study design and communication.

Strategy 5: Demonstrate research relevance to users and stakeholders.

Strategy 6: Follow through with fire science stakeholders to ensure that transferred knowledge and tools are applied or adopted by users, to determine if mechanisms for technology and knowledge transfer were effective, and to identify any barriers to implementation or adoption of the science provided.

Strategy 7: Evaluate effectiveness of science delivery practices after technology transfer to identify areas for improvement that can be applied in the future.

Strategy 8: Maintain and support a diverse stakeholderdriven science portfolio that is applicable to and synthesized for management organizations.

Strategy 9: Recognize the importance of multiplestakeholder or broad-scale projects as well as projects designed to meet specific needs at local scales.

\section{Priority 3: Effectively Communicate USGS Fire Science Capacity, Products, and Information to a Broad Audience}

Effective science communication to external audiences identifies the USGS as a leader in wildland fire science and ensures that critical information is broadly available to stakeholders such as Congress, the public, and potential new partners. Within the USGS, internal communication is critical for coordinating science activity and maintaining consistent science messaging across the organization. Through strategically managed internal and external communication, designed to build and maintain relationships with all audiences, the USGS can implement outreach efforts that serve the needs of those who have high interest in, and are affected by, our fire science.

\section{Goal 1: Establish and maintain communication pathways for outreach to external audiences}

Key external audiences include the fire science stakeholder community, the Joint Fire Science Program and its Fire Science Exchange Network, the DOI leadership and offices, White House offices, congressional members and staffers, and the public affected by wildland fire. Key strategies for effective external communication recognize the diverse suite of entities to whom communications need to be directed, and target best practices for outreach, as follows:

Strategy 1: Maintain an information-rich USGS fire science website that contains USGS fire science publications, scientist biographies and contact information, fact sheets, data syntheses, and links to databases, tools, other science products, and short stories for social media and communication outlets.

Strategy 2: Publish a quarterly USGS fire science newsletter that updates partners on new wildland fire research efforts, recently published studies, and outreach including conferences, webinars, and science co-production and collaboration opportunities.

Strategy 3: Publish an annual report and updated annotated bibliography of USGS fire science research.

Strategy 4: Conduct frequent science presentations and information sharing with the Joint Fire Science Program's Fire Science Exchange Network to improve fire science outreach.

Strategy 5: Hold periodic USGS-led wildland fire workshops, symposia, seminars, roundtables and other gatherings in stand-alone format or in association with conferences and meetings.

Strategy 6: Regularly interact with and brief critical fire management organizations such as the Wildland Fire Leadership Council, Fire Executive Council, and National Wildfire Coordinating Group on USGS wildland fire science capabilities and emerging information, data, and tools.

Strategy 7: Regularly brief DOI leadership and, in particular, engage with the DOI Office of Wildland Fire which oversees wildland fire management with agency leadership.

Strategy 8: Engage Congress at both the national and local level to inform leaders and staffers on key USGS wildland fire science that contributes to the protection of constituents and communities. 


\section{Successful Communication of}

\section{U.S. Geological Survey (USGS) Fire Science}

- USGS fire science is communicated to external and internal audiences in a clear, effective, and timely manner.

- USGS fire science is recognized internally and externally, and stakeholders help propagate USGS wildland fire messaging.

- Land managers are aware of and have access to USGS fire science research products, data, and tools.

- Stakeholders can identify USGS wildland science expertise, capacity, and research strengths.

- USGS scientists, program managers, and staff are invested in the USGS wildland fire program, participate in the wildland fire science community of practice, and drive outreach efforts to external audiences.

- The USGS fire science website is used by a variety of audiences as a source for information.

- USGS fire scientists communicate and collaborate with the Joint Fire Science Program's Fire Science Exchange Network to improve fire science outreach.

- As the result of enhanced communication, USGS leadership understand, support, and are invested in the wildland fire science program of work.

- U.S. Department of the Interior leadership supports and understands the scope of USGS fire science and use fire science information in decision making.

\section{Goal 2: Establish and maintain communication pathways for outreach to internal audiences}

Key internal audiences include scientists, communication specialists, and senior leadership within the USGS. Centralized internal communications foster collaborations among USGS scientists and programs, diversify and expand the scope of USGS fire science, and help build and solidify internal relationships and science messaging among USGS researchers and leadership. Critical strategies for internal fire science communication include the following:

Strategy 1: Develop the USGS wildland fire science community of practice $(\mathrm{CoP})$ as the primary forum for coordinating fire science and sharing information among USGS scientists from a variety of programs, regions, and research fields; communications specialists; and senior leadership. Hold regular meetings of the $\mathrm{CoP}$ to provide updates on current and recently published USGS fire science, national fire activity levels and management needs, funding opportunities, and news about recent legislative, secretarial, and administrative actions that are important to the fire science community.

Strategy 2: Deliver briefings to USGS leadership (for example, Executive Leadership Team and Hazard Response Executive Council) on USGS wildland fire science progress and broader status of and issues in fire research and management communities.

Strategy 3: Publish articles, leadership blogs, and science spotlights within internal USGS publications (for example, the Need to Know digest) to share wildland fire science activities and internal collaborations with the USGS workforce.

Strategy 4: Work directly with other communication and outreach staff across USGS on annual wildland fire science communications planning, including strategies for audiencespecific outreach.

Strategy 5: Work to develop outreach products such as science websites, articles, podcasts, and social media that showcase science from multiple USGS efforts on wildland fire research and development. 


\section{Priority 4: Enhance USGS Organizational Structure and Support for Fire Science}

Organizational structure and support that improves wildland fire science coordination and cooperation within and outside the USGS is requisite for accomplishing science goals and ensuring stakeholder engagement and effective science communication. The USGS has over 100 scientists researching fire-related topics across disciplines in many different science centers across all of the USGS mission areas and regions, and its investment in fire science includes tens of millions of dollars per year that funds 100 to 200 ongoing fire-related projects, the production of numerous data and tools, and 70 to 90 publications annually. Many of these fire-focused projects address with equal emphasis other USGS priorities such as invasive species, water resources, drought, endangered species, and land use management, thus illustrating the integrative and complex nature of fire-related issues and required research. The USGS can better meet the goals of the Cohesive Strategy and the directions from Congress and administrations with a science organization that is integrated, efficient, and adaptive towards meeting the needs of stakeholders, as described in the goals and strategies below.

\section{Goal 1: Strengthen the USGS fire science organizational structure to enhance fire science coordination and prioritize critical fire science needs}

Currently, a Fire Science Coordinator within the USGS has the primary, assigned institutional role of providing fire science leadership across multiple USGS mission areas; coordinating fire science technical support to the DOI and its Office of Wildland Fire (OWF, the office responsible for maintaining a unified Wildland Fire Management Program across the DOI) and external agencies and organizations; facilitating communication of USGS fire science within the USGS and to external partners; representing the USGS and OWF in intra-agency and interagency meetings, workshops, symposia, and planning sessions; and providing program guidance and developing policies as needed. The Fire Science Coordinator also leads internal fire science coordination via the USGS fire science community of practice (CoP), a highly valuable, collaborative entity that maintains cohesion and identity for USGS fire scientists through organized monthly teleconferences, scientific presentation series, and USGS symposia at professional society meetings. Participation in the $\mathrm{CoP}$ is voluntary and open to all interested USGS staff, including scientists, administrators, and executive leadership.

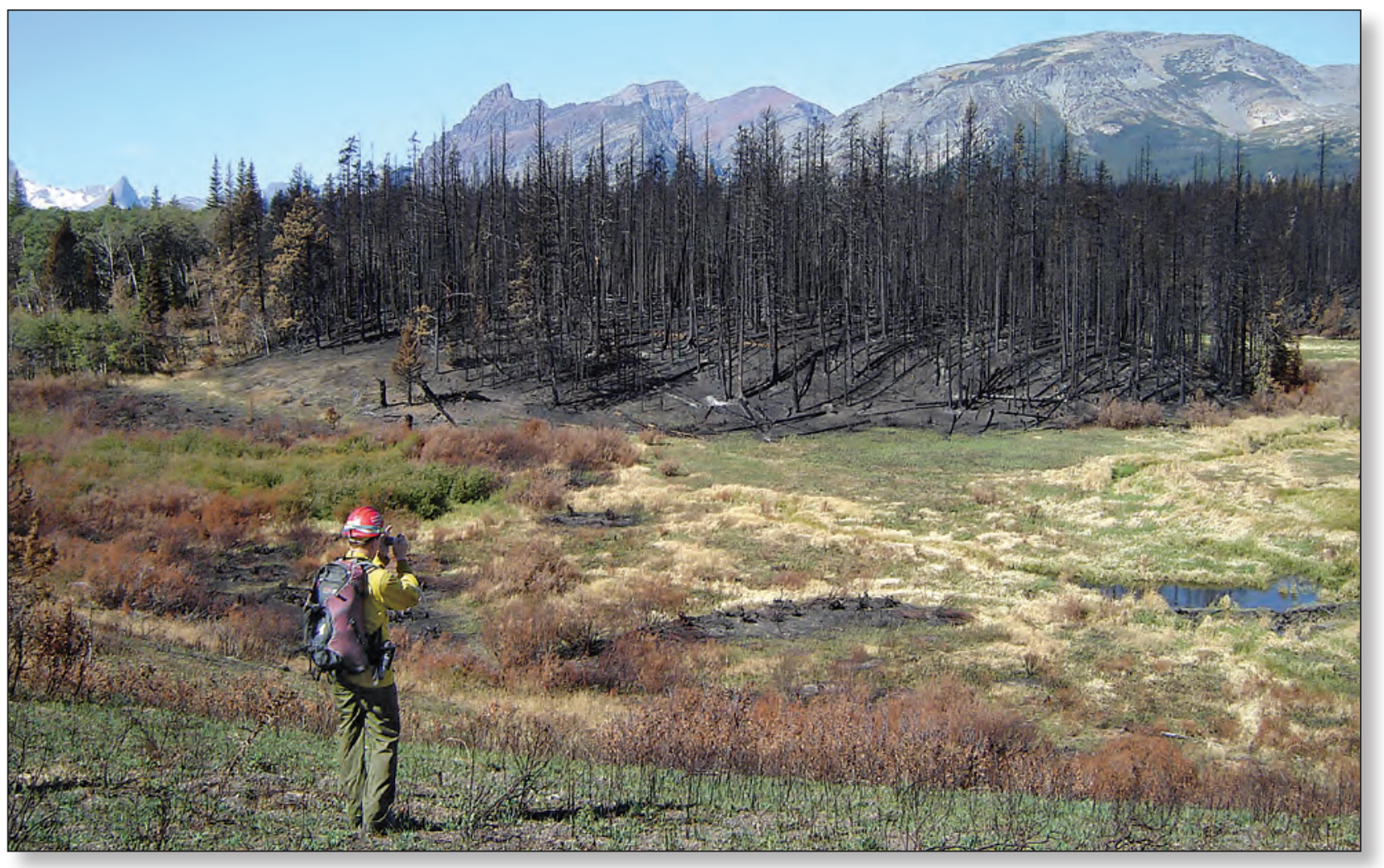

A fire ecologist takes pictures of the location of the Red Eagle fire in Montana, 2007. Photograph by U.S. Geological Survey. 
Strategy 1: Expand fire science capability and cohesion within the USGS through an enhanced fire science organizational structure. A clearly defined USGS fire science organization will improve the agency's ability to address stakeholder, departmental, congressional, and administration priorities. The USGS fire science CoP is not a sufficient mechanism on its own for overall fire science coordination, especially given the distributed fire science capacity across all mission areas, the absence of a fire science administrative structure, and the lack of a clearly demarcated budget directed to fire science spending - the majority of which is interwoven into complex and interdisciplinary work. Enhancements to the current fire science organizational structure described below will provide mechanisms to help direct and focus USGS fire science research emphases on topics of highest priority to stakeholders, DOI, Congress, and the administration. Nonexclusive actions to expand USGS fire science capability and cohesion include the following:

A. Develop a chartered Wildland Fire Science Team or Program Council with representation from the different mission areas, regions, and centers that participate in wildland fire research at the USGS that will coordinate with USGS leadership to implement the Strategic Plan, develop fire science priorities, engage in the budget process, commit resources, respond to data calls, and produce summary reports.

B. Colocate a USGS employee at the National Interagency Fire Center (NIFC) in Boise, Idaho, to assist with fire coordination within the USGS and to facilitate communications with NIFC partners. Working from the central hub for fire management in the United States, NIFC engagement and colocation would allow this position to liaise and collaborate with the broader fire science and management communities.

These actions will support each other to enhance the substantial USGS fire science capacity and its potential to inform and interface with the myriad other areas of USGS science affected by wildland fire.

\section{Successful Organizational Structure and Support for U.S. Geological Survey (USGS) Fire Science}

- USGS fire science is organized to help efficiently direct and prioritize research to meet the most pressing and timely needs of stakeholders.

- Funding is available through the annual budget process for critical and dedicated USGS fire positions that provide internal and external coordination of fire-connected work and facilitate communication and collaboration with external partners and stakeholders.

- USGS scientists and managers demonstrate leadership through participation in fire science and management organizations.

- Other science organizations engage with USGS to make use of its unique capacity.

- USGS science is collaborative across agencies, programs, and organizations. Partners include the U.S. Department of Agriculture Forest Service, Joint Fire Science Program, National Aeronautics and Space Administration, National Oceanic and Atmospheric Administration, U.S. Departments of Defense and Energy, universities, other science organizations, and fire, land, and resource managers from Federal, State, Tribal, and nongovernmental organizations. 
Goal 2: Strengthen external partnerships to meet national fire science priorities and provide fire science leadership

Among science producers, the USGS is not the sole source of wildland fire science information in the United States. Other government agencies (for example, USFS Research \& Development), nongovernmental organizations, and university scientists are also active members of the wildland fire science community and maintain expertise that complements USGS science, data, products, and tools. Ideally, USGS scientists should be able to easily identify and partner with appropriate fire science entities. These partnerships could better leverage expertise and resources to ensure that efforts are complementary and collaborative, thus efficiently producing priority science. By increasing awareness and coordination of the unique capacity possessed by the USGS, greater opportunities will exist for collaboration with other Federal agencies (for example, Federal Emergency Management Agency, FEMA; National Aeronautics and Space Administration, NASA; National Institute of Standards and Technology, NIST; National Oceanic and Atmospheric Association, NOAA; National Science Foundation, NSF; U.S. Department of Agriculture, Agricultural Research Service, ARS; U.S. Army Corps of Engineers, USACE; U.S. Department of Defense (DOD); U.S. Department of Energy, DOE; U.S. Department of Agriculture, Forest Service Research \& Development; and U.S. Environmental Protection Agency, EPA) and non-Federal organizations. With different organizations contributing their own unique abilities, greater opportunities to address the biggest wildland fire challenges will emerge. Suggested strategies by which USGS fire scientists can establish relationships with other fire science organizations and entities include the following:

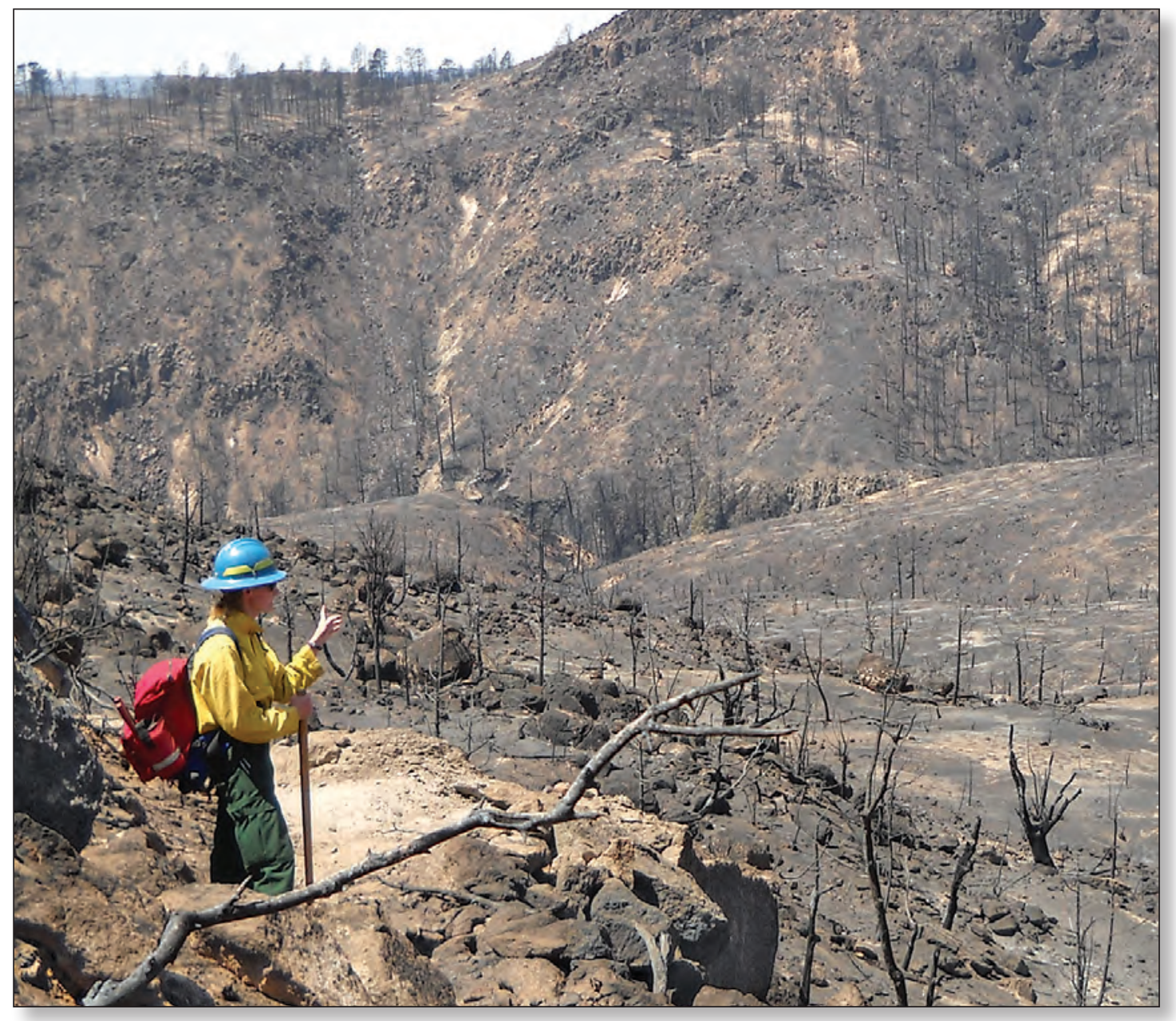

A U.S. Geological Survey (USGS) scientist surveying fire effects after the Las Conchas fire in New Mexico, 2011. Photograph by U.S. Geological Survey. 
Strategy 1: Consistent with existing charters, provide continuous USGS leadership to engage with and meet ongoing responsibilities to the Joint Fire Science Program, the Wildland Fire Leadership Council, the Fire Executive Council, and the Wildland Fire Information and Technology organization. These organizations are unique partnerships of fire stakeholders that address the major challenges posed by wildland fire in the United States.

Strategy 2: Participate in leadership positions in key fire organizations. By working with fire organizations, USGS scientists can improve their understanding of stakeholder needs and can help promote the USGS science capacity and maintain its position as a cutting-edge science organization. Potential organizations within which USGS scientists could act in leadership roles include National Wildfire Coordinating Group committees, Cohesive Strategy Regional Committees, regional boards of the Joint Fire Science Program Fire Science Exchange Network, and State Prescribed Fire Councils, among others. For these organizations, committees are the forums that define the information, data, and tools required by the inter-operational fire management community. Engagement of USGS staff in these discussions contributes expertise and informs USGS of needs as they are defined.

Strategy 3: Become involved through leadership and voluntary service positions with professional societies, fire-specific organizations, and technical working groups. Advancement of fire science and USGS contribution can be fostered by editorship of peer-reviewed publications (series and special editions), organizing science symposia or roundtables, addressing topics in technical workgroups, building relationships and collaborations, and fostering communication. Representative key organizations include the Association for Fire Ecology and the International Association of Wildland Fire or workgroups in other professional societies.

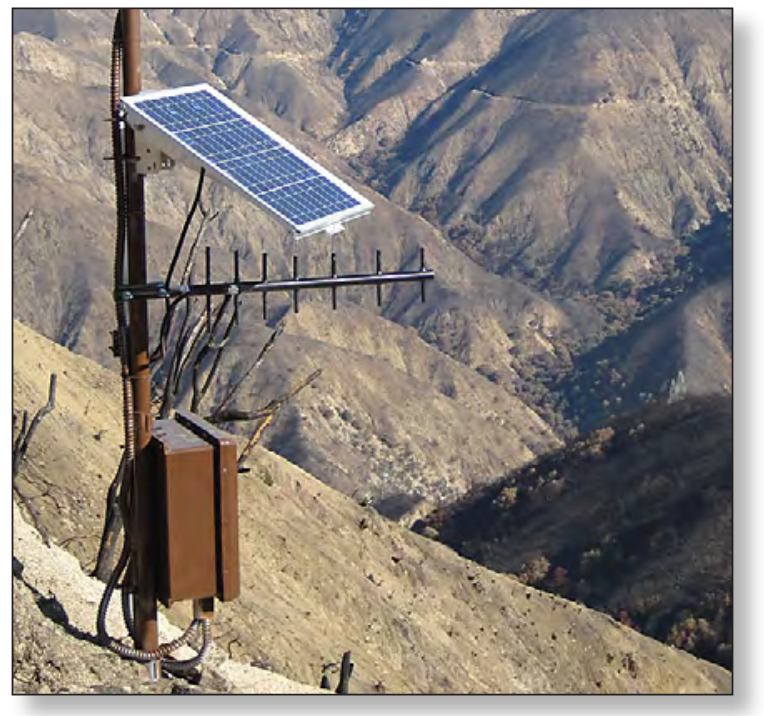

\section{Strategic Plan Implementation and Evaluation}

Strategic planning is an ongoing process that centers on the assessment, decisions, and actions undertaken to create and sustain meaningful and successful forward progress. We recommend the following steps to assess, implement, and evaluate the Strategic Plan:

\section{Assessment}

- Review the Strategic Plan, including its priorities and their alignment with overall DOI and USGS priorities.

- Review the internal environment related to fire science, including resources, personnel and competencies, and internal priorities and science and information needs.

- Review the external environment related to fire science, including external priorities and science and information needs and activities of stakeholders and collaborators.

\section{Implementation}

- Set annual objectives and revise procedures to meet objectives.

- Communicate and clarify strategic goals and objectives to internal and external audiences.

- Maintain coordination between and among USGS scientists, leadership, and stakeholders to facilitate forward progress.

- Allocate sufficient resources to accomplish objectives.

- Perform activities to meet objectives.

\section{Evaluation}

- Develop indicators and means for measuring success.

- Establish a system to evaluate success according to these indicators.

- Communicate evaluation methods and metrics to internal and external audiences. 


\section{Conclusions}

The four integrated priorities of the USGS Wildland Fire Science Strategic Plan are intended to define the unique niche and groundbreaking aspects of USGS fire science, enhance engagement with stakeholders, improve fire science communication and delivery, and define organizational structure and support to better meet science and stakeholder needs. By addressing fire science challenges explicitly outlined in the National Cohesive Wildland Fire Management Strategy and in the 2017 USGS Council of Senior Scientist Advisors (COSSA) report, this Strategic Plan identifies achievable strategies and a cohesive path forward that will more effectively focus resources and build partnerships to meet the information needs of fire, land, and emergency managers and natural and human communities affected by wildfire. Essential to the success of the Strategic Plan are improving efforts to work across USGS mission areas and disciplines and adopting an "All Hands, All Lands" management perspective that increases collaboration among Federal, State, Tribal, and local officials, land managers, and the fire community to accomplish the goals of the Cohesive Strategy. The USGS is committed to enhancing its national wildland fire research capacity to provide scientific analysis, data, and tools that inform current and future fire management decisions in the 21 st century.

\section{References Cited}

Allen, C.D., Macalady, A.K., Chenchouni, H., Bachelet, D., McDowell, N., Vennetier, M., Kitzberger, T., Rigling, A., Breshears, D.D., Hogg, E.H., Gonzalez, P., Fensham, R., Zhang, Z., Castro, J., Demidova, N., Lim, J.-H., Allard, G., Running, S.W., Semerci, A., and Cobb, N., 2010, A global overview of drought and heat-induced tree mortality reveals emerging climate change risks for forests: Forest Ecology and Management, v. 259, no. 4, p. 660-684. [Also available at https://doi.org/10.1016/j.foreco.2009.09.001.]

Allen, C.D., Savage, M., Falk, D.A., Suckling, K.F., Swetnam, T.W., Schulke, T., Stacey, P.B., Morgan, P., Hoffman, M., and Klingel, J.T., 2002, Ecological restoration of southwestern ponderosa pine ecosystems-A broad perspective: Ecological Applications, v. 12, no. 5, p. 1418-1433. [Also available at https://doi.org/10.1890/ 1051-0761(2002)012[1418:EROSPP]2.0.CO;2.]

Balch, J.K., Bradley, B.A., Abatzoglou, J.T., Nagy, R.C., Fusco, E.J., and Mahood, A.L., 2017, Human-started wildfires expand the fire niche across the United States: Proceedings of the National Academy of Sciences of the United States of America, v. 114, no. 11, p. 2946-2951. [Also available at https://doi.org/10.1073/pnas.1617394114.]
Bowman, D.M.J.S., Balch, J., Artaxo, P., Bond, W.J., Cochrane, M.A., D’Antonio, C.M., DeFries, R., Johnston, F.H., Keeley, J.E., Krawchuk, M.A., Kull, C.A., Mack, M., Moritz, M.A., Pyne, S., Roos, C.I., Scott, A.C., Sodhi, N.S., and Swetnam, T.W., 2011, The human dimension of fire regimes on Earth: Journal of Biogeography, v. 38 , no. 12, p. 2223-2236. [Also available at https://doi.org/10.1111/j.1365-2699.2011.02595.x.]

Butsic, V., Kelly, M., and Moritz, M.A., 2015, Land use and wildfire-A review of local interactions and teleconnections: Land (Basel), v. 4, no. 1, p. 140-156. [Also available at https://doi.org/10.3390/land4010140.]

Clark, J.A., Loehman, R.A., and Keane, R.E., 2017, Climate changes and wildfire alter vegetation of Yellowstone National Park, but forest cover persists: Ecosphere, v. 8, no. 1, article e01636, 16 p. [Also available at https://doi.org/10.1002/ecs2.1636.]

Coates, P.S., Ricca, M.A., Prochazka, B.G., Brooks, M.L., Doherty, K.E., Kroger, T., Blomberg, E.J., Hagen, C.A., and Casazza, M.L., 2016, Wildfire, climate, and invasive grass interactions negatively impact an indicator species by reshaping sagebrush ecosystems: Proceedings of the National Academy of Sciences of the United States of America, v. 113, no. 45, p. 12745-12750. [Also available at https://doi.org/10.1073/pnas.1606898113.]

Jenni, K.E., Goldhaber, M.B., Betancourt, J.L., Baron, J.S., Bristol, R.S., Cantrill, M., Exter, P.E., Focazio, M.J., Haines, J.W., Hay, L.E., Hsu, L., Labson, V.F., Lafferty, K.D., Ludwig, K.A., Milly, P.C., Morelli, T.L., Morman, S.A., Nassar, N.T., Newman, T.R., Ostroff, A.C., Read, J.S., Reed, S.C., Shapiro, C.D., Smith, R.A., Sanford, W.E., Sohl, T.L., Stets, E.G., Terando, A.J., Tillitt, D.E., Tischler, M.A., Toccalino, P.L., Wald, D.J., Waldrop, M.P., Wein, A., Weltzin, J.F., and Zimmerman, C.E., 2017, Grand challenges for integrated USGS science-A workshop report: U.S. Geological Survey Open-File Report 2017-1076, 94 p. [Also available at https://doi.org/10.3133/ofr20171076.]

Liu, Z., Wimberly, M.C., Lamsal, A., Sohl, T.L., and Hawbaker, T.J., 2015, Climate change and wildfire risk in an expanding wildland-urban interface-A case study from the Colorado Front Range Corridor: Landscape Ecology, v. 30, no. 10, p. 1943-1957. [Also available at https://doi.org/10.1007/s10980-015-0222-4.]

Loehman, R.A., Keane, R.E., and Holsinger, L.M., 2020, Simulation modeling of complex climate, wildfire, and vegetation dynamics to address wicked problems in land management: Frontiers in Forests and Global Change, v. 3, article 3. [Also available at https://doi.org/10.3389/ ffgc.2020.00003.] 
Loehman, R.A., Reinhardt, E., and Riley, K.L., 2014, Wildland fire emissions, carbon, and climate-Seeing the forest and the trees-A cross-scale assessment of wildfire and carbon dynamics in fire-prone, forested ecosystems: Forest Ecology and Management, v. 317, p. 9-19. [Also available at https://doi.org/10.1016/j.foreco.2013.04.014.]

National Interagency Fire Center, 2020, StatisticsHistorical wildland fire information: National Interagency Fire Center web page, accessed May 20, 2020, at https://www.nifc.gov/fireInfo/fireInfo_statistics.html.

National Wildfire Coordinating Group, 2018, NWCG glossary of wildland fire: National Wildfire Coordinating Group, PMS 205, accessed May 20, 2020, at https://www.nwcg.gov/glossary/a-z.

North, M.P., Stephens, S.L., Collins, B.M., Agee, J.K., Aplet, G., Franklin, J.F., and Fulé, P.Z., 2015, Reform forest fire management: Science, v. 349, no. 6254, p. 1280-1281. [Also available at https://doi.org/10.1126/science.aab2356.]

Pausas, J.G., and Keeley, J.E., 2019, Wildfires as an ecosystem service: Frontiers in Ecology and the Environment, v. 17, no. 5, p. 289-295. [Also available at https://doi.org/10.1002/fee.2044.]

Radeloff, V.C., Helmers, D.P., Kramer, H.A., Mockrin, M.H., Alexandre, P.M., Bar-Massada, A., Butsic, V., Hawbaker, T.J., Martinuzzi, S., Syphard, A.D., and Stewart, S.I., 2018, Rapid growth of the US wildland-urban interface raises wildfire risk: Proceedings of the National Academy of Sciences of the United States of America, v. 115 , no. 13 , p. 3314-3319. [Also available at https://doi.org/10.1073/pnas.1718850115.]

Sankey, J.B., Kreitler, J., Hawbaker, T.J., McVay, J.L., Miller, M.E., Mueller, E.R., Vaillant, N.M., Lowe, S.E., and Sankey, T.T., 2017, Climate, wildfire, and erosion ensemble foretells more sediment in western USA watersheds: Geophysical Research Letters, v. 44, no. 17, p. 8884-8892. [Also available at https://doi.org/10.1002/2017GL073979.]

Schoennagel, T., Balch, J.K., Brenkert-Smith, H., Dennison, P.E., Harvey, B.J., Krawchuk, M.A., Mietkiewicz, N., Morgan, P., Moritz, M.A., Rasker, R., Turner, M.G., and Whitlock, C., 2017, Adapt to more wildfire in western North American forests as climate changes: Proceedings of the National Academy of Sciences of the United States of America, v. 114, no. 18, p. 4582-4590. [Also available at https://doi.org/10.1073/ pnas.1617464114.]

Steblein, P.F., and Miller, M.P., 2019, Characterizing 12 years of wildland fire science at the U.S. Geological SurveyWildland fire science publications, 2006-17: U.S. Geological Survey Open-File Report 2019-1002, 67 p. [Also available at https://doi.org/10.3133/ofr20191002.]
Stephens, S.L., Collins, B.M., Biber, E., and Fulé, P.Z., 2016, U.S. Federal fire and forest policy-Emphasizing resilience in dry forests: Ecosphere, v. 7, no. 11, article e01584, 19 p. [Also available at https://doi.org/10.1002/ecs2.1584.]

Syphard, A.D., Keeley, J.E., Pfaff, A.H., and Ferschweiler, K., 2017, Human presence diminishes the importance of climate in driving fire activity across the United States: Proceedings of the National Academy of Sciences of the United States of America, v. 114, no. 52, p. 13750-13755. [Also available at https://doi.org/10.1073/pnas.1713885114.]

U.S. Geological Survey, 2020, Boundaries-National boundary dataset: U.S. Geological Survey The National Map web page, accessed May 20, 2020, at https://viewer.nationalmap.gov/datasets/.

van Mantgem, P.J., Stephenson, N.L., Byrne, J.C., Daniels, L.D., Franklin, J.F., Fulé, P.Z., Harmon, M.E., Larson, A.J., Smith, J.M., Taylor, A.H., and Veblen, T.T., 2009, Widespread increase of tree mortality rates in the western United States: Science, v. 323, no. 5913, p. 521-524. [Also available at https://doi.org/10.1126/science.1165000.]

van Mantgem, P.J., Stephenson, N.L., Knapp, E., Battles, J., and Keeley, J.E., 2011, Long-term effects of prescribed fire on mixed conifer forest structure in the Sierra Nevada, California: Forest Ecology and Management, v. 261, no. 6, p. 989-994. [Also available at https://doi.org/10.1016/ j.foreco.2010.12.013.]

Vogel, J.A., Debinski, D.M., Koford, R.R., and Miller, J.R., 2007, Butterfly responses to prairie restoration through fire and grazing: Biological Conservation, v. 140, nos. 1-2, p. 78-90. [Also available at https://doi.org/10.1016/ j.biocon.2007.07.027.]

Wildland Fire Leadership Council, 2014, The national strategy-The final phase in the development of the National Cohesive Wildland Fire Management Strategy: Washington, DC, Wildland Fire Leadership Council, 93 p., accessed December 11, 2015, at https://www.forestsandrangelands. gov/strategy/documents/strategy/CSPhaseIIINational StrategyApr2014.pdf.

Winter, S.L., Fuhlendorf, S.D., Goad, C.L., Davis, C.A., Hickman, K.R., and Leslie, D.M., Jr., 2012, Restoration of the fire-grazing interaction in Artemisia filifolia shrubland: Journal of Applied Ecology, v. 49, no. 1, p. 242-250. [Also available at https://doi.org/10.1111/j.13652664.2011.02067.x.]

Wright, V., 2010, Challenges to implementing "best available science": Fire Science Brief, no. 124, p. 1-6. [Also available at https://www.firescience.gov/projects/ briefs/04-4-2-01_FSBrief124.pdf.] 


\section{Appendix 1. Summary of Discussions of Fire Science With Stakeholders}

\section{Background}

During 2019 and 2020, U.S. Geological Survey (USGS) fire scientists held 31 discussion sessions with 40 individuals representing a wide variety of stakeholder organizations from the U.S. wildland fire community. Although the set of organizations contacted is neither comprehensive nor necessarily representative of all important stakeholders of USGS fire science, the organizations span a wide spectrum including Federal agencies both within and outside the U.S. Department of the Interior, nongovernmental organizations with an interest in wildland fire, Tribal entities, State and county organizations, and the Joint Fire Science Program's Fire Science Exchange Network (fig. 1.1).

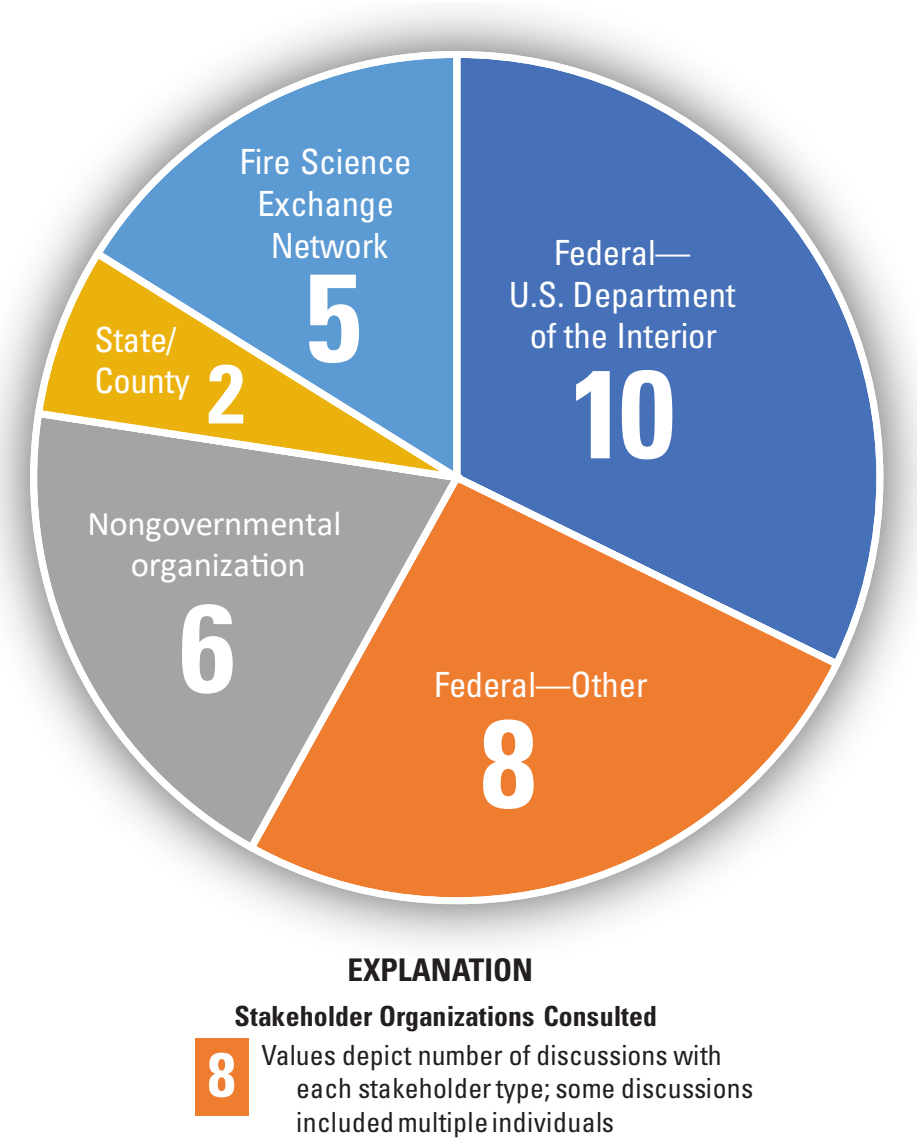

Figure 1.1. Types of organizations participating in the 31 fire science discussions between the U.S. Geological Survey and stakeholders.
Discussions were conducted specifically to attain a better understanding of stakeholder perspectives on key sources of fire science information, needs for fire information data and tools, and challenges or opportunities in building fire science partnerships. A broad variety of organizations and individuals were approached to ensure coverage of perspectives from regional to national scales, among science producers and users, and for governmental and nongovernmental organizations. Some discussions included multiple individuals. The timing of the discussions was staged so that results could inform the development of a fire science strategic plan for the USGS. Discussions were conducted in person or via phone or video calls, over the course of several months, with an open, informal format.

\section{Information Gathering Process}

Discussions were framed in a manner that allowed stakeholders to share their insights and perceptions on a number of fire-related topics and the USGS's ability to meet their fire science needs. Five key topics were addressed:

1. How stakeholders learn about new fire science that is applicable to their organizations;

2. Stakeholders' familiarity with the various USGS research activities and capabilities related to fire science and their use of any USGS fire science products to inform decision making;

3. Whether the stakeholders' organizations have ever collaborated with USGS on a research topic, as well as specific impediments to be overcome and (or) ways that collaborations could be made more effective in the future;

4. Stakeholders' perceptions of their organizations' specific needs (including information, data, or tools) that could be provided by the USGS in the future; and

5. Stakeholders' perceptions of the most pressing science needs for fire managers in the near-term (within 10 years) and longer term (10 years and beyond). 


\section{Analysis of Stakeholder Discussions}

The discussions with stakeholders were analyzed and compiled to identify concepts and determine common themes. The analysis process followed standard qualitative social science techniques, through which detailed information from individual discussions is condensed into essential underlying categories and themes.

\section{Methods}

Data were gathered, coded, and analyzed following an iterative process. First, the USGS fire science representative who facilitated a particular conversation recorded discussion notes for each of the key topics identified above. Next, a primary coder analyzed these data in NVivo qualitative data analysis software, a program that enables researchers to extract information from unstructured, text-based sources (Welsh, 2002). The analysis used an inductive coding approach in which phrases in the raw data (discussion notes) were assigned codes that corresponded to detailed underlying concepts ("categories"). While coding necessarily omits details and context, it is intended to concisely capture the main idea or topic of a phrase. For example, in discussions about pressing, future fire management information needs the phrases "Climate change impacts, particularly in arid lands, and how these will affect resilience to fire" and "Climate change impacts on fire regimes - timing, length of season, behavior," were both assigned the code "climate."

The coder subsequently grouped categorical responses into more generalized themes based on commonalities. To continue the example above, codes for "climate," "fuels, fire behavior," and "social science, human dimensions," along with others, were all grouped into the theme "priority research needs." Next, three other individuals sequentially reviewed and refined the coding and organization, after which the primary coder incorporated all recommended changes and conducted any final refinements deemed necessary. Finally, the frequency of categories and themes within each key topic area were converted into the summary graphics provided below.

\section{Limitations and Caveats}

While every effort has been made to faithfully capture the spirit and content of the discussions, summarized results may fail to capture important nuances and details conveyed or implied by the stakeholders. We endeavored to solicit unbiased information from the stakeholders, but the discussions and notetaking were not conducted by trained, impartial interviewers. As is inherent to the qualitative analysis process, coding and its organization requires subjective interpretations by the analysis team, including determining the "best fit" when a reference represents multiple coded concepts. Further, because stakeholders did not select items from a prepared list, nor did discussions prompt for information about specific concepts related to individual codes, summarized results reflect top priorities of the stakeholders but are not necessarily comprehensive of the stakeholders' perspectives. Finally, no attempt has been made to weight responses by different stakeholders or by the strength of the conveyed perspectives; tallies depicted in the summary graphics below demonstrate the simple frequencies with which different concepts were mentioned by stakeholders in the discussions.

\section{Results of Stakeholder Discussions}

The categories and themes offered by stakeholders are summarized in the graphics below, which are organized by the five key topics of the discussions. These results provide key insights, including the diversity of responses and commonalities across discussions. 


\section{Learning About USGS Fire Science}

Discussions indicated that stakeholders use a wide variety of approaches to learn about new fire science that may be useful to their organizations (fig. 1.2). The predominant method is through interactions with specific individuals within the USGS, including fire science leadership and individual scientists. Additional opportunities for one-on-one interactions, including meetings, conferences, and webinars, were also frequently mentioned. Consistent with its large footprint at the nexus of fire science and its application, the Joint Fire Science Program and the Fire Science Exchange Network were also frequently mentioned as important. Other information channels frequently noted include email, listservs, and news media; agencies and agency libraries; and social media. More traditional academic outlets, including scholarly databases, scientific journals, research institutions, and professional societies, were also noted as important information channels. Finally, numerous stakeholders mentioned a reliance on general internet searches.

\section{Familiarity With USGS Fire Science}

Stakeholders' responses related to their expressed familiarity with USGS research activities and capabilities were highly variable, with few indicating a complete knowledge of the full complement of fire-related research produced by USGS. Figure 1.3 depicts stated levels of familiarity with USGS fire science, with specific descriptors indicating level of familiarity shown in the outer ring and theme groupings shown in the inner ring. Only 20 percent of stakeholders conveyed that they were very familiar with USGS fire science. The majority (54 percent) expressed a moderate level of familiarity, whereas 27 percent expressed that they were not very familiar with USGS fire science.

In discussions, stakeholders commonly reported knowing of remote sensing, mapping, and data delivery products including Monitoring Trends in Burn Severity (MTBS), Landscape Fire and Resource Management Planning Tools (LANDFIRE), and Geospatial Multi-Agency Coordination (GeoMAC); stakeholders also found these products helpful for decision making. In some cases, stakeholders were primarily familiar with work performed by individual scientists yet possessed little familiarity with the broader, USGS-wide capacity.

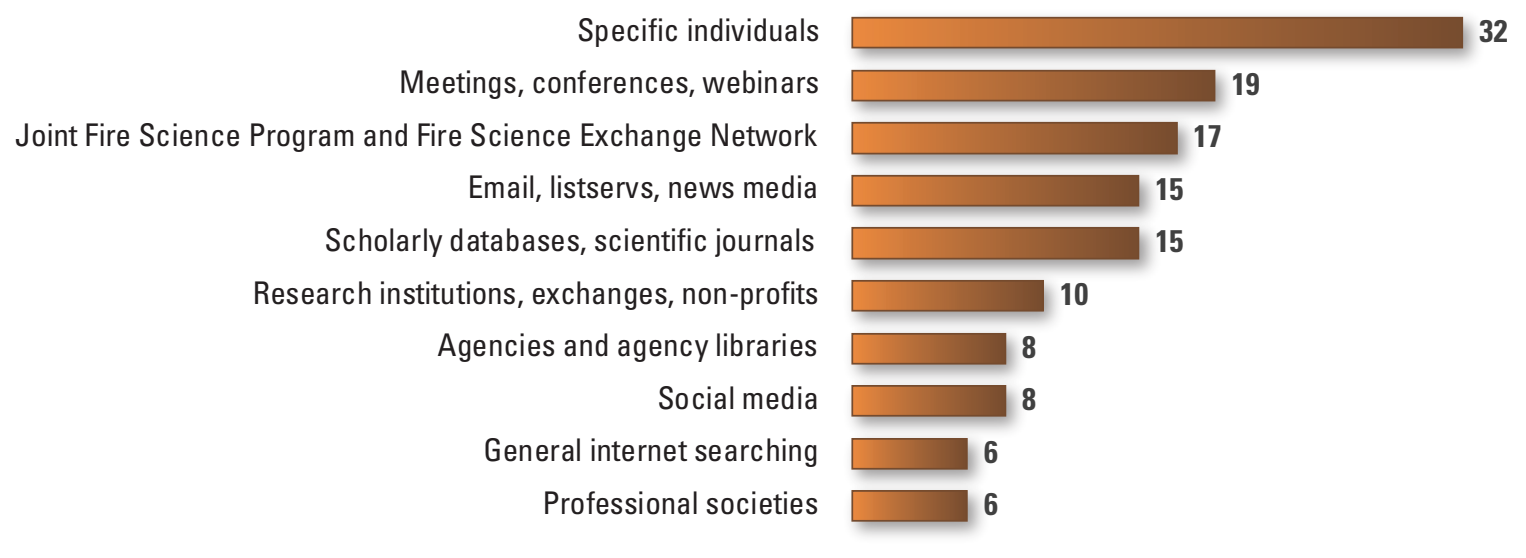

Figure 1.2. Number of times source types for fire science information were identified during stakeholder discussions. 


\section{Impediments to Stakeholder Engagement and Collaboration With USGS on Fire Science}

All stakeholders indicated that they have collaborated with the USGS in the past, although not necessarily on a firerelated topic. They also described numerous impediments to working together more effectively (fig. 1.4). Top impediments included USGS organization and operations; funding, costs, and resources; and a lack of information about or awareness of relevant USGS science and capabilities.

Many of the perceived impediments relate to USGS structure and policy in general and are not specific to USGS fire science. USGS organization and operations were the most frequently noted impediment. For example, multiple stakeholders mentioned that inconsistent models across USGS cost centers can create issues or lead to regional variation in their relationships with the USGS. Others mentioned the USGS's emphasis on academic research, or "the publish or perish model that USGS is under," limits collaboration. Another frequently noted category - funding, cost, and resourcesreflects not only a perspective of insufficient stakeholder resources for collaboration in general but also a common notion that overhead rates are too high. As one stakeholder mentioned, "Cost is considered high, and overhead is a part of it. [We] consider USGS a Cadillac but pricing structure is perceived as expensive." Although the least frequently mentioned impediment, two stakeholders identified a concern about maintaining control over and (or) privacy of their data.

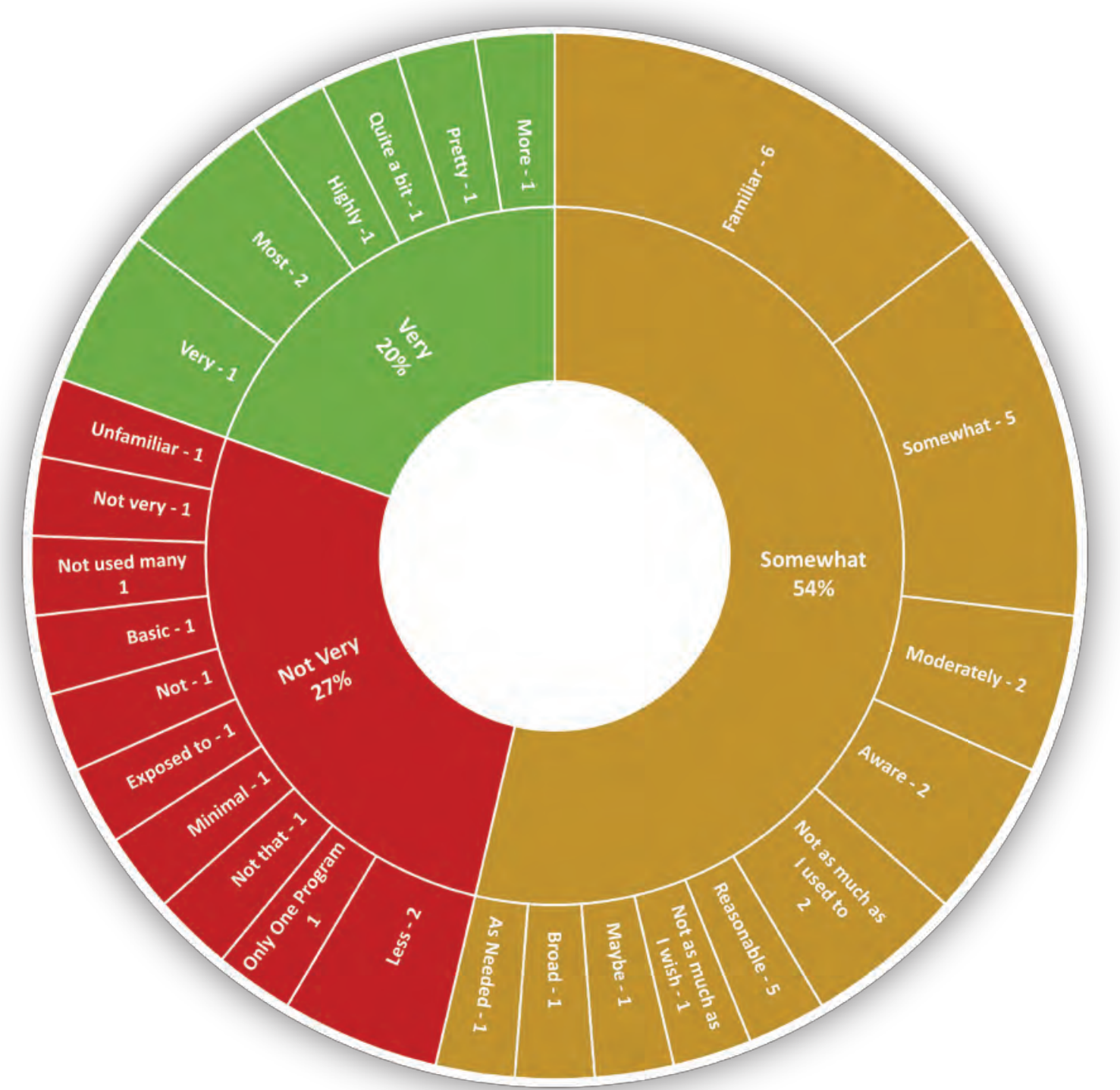

Figure 1.3. Frequency of terms used to describe level of familiarity with U.S. Geological Survey fire science (outer ring), organized into three levels of familiarity (inner ring). 
Other perceived impediments are more closely linked to the USGS fire science community and its operations. Consistent with results shown in figure 1.3 above, many stakeholders described a lack of information or awareness about USGS fire science, at times linking this to shortcomings of communication and outreach by USGS and lack of involvement by the USGS in certain (geographic or topical) areas. Specific suggestions include a "directory of USGS scientists, locations, and key topics," an external-facing newsletter, and greater opportunities for seminars and tours. Some stakeholders also expressed concern about what they see as a lack of actionable science, both in terms of research not necessarily reflecting relevant management agency questions and in terms of results being presented with limited interpretation or recommendations for how practitioners can apply the science. Finally, a few stakeholders mentioned impediments to collaboration that relate specifically to interpersonal conflict and the attitudes of individual (potential) collaborators.

\section{Stakeholder Needs Targeted to the USGS}

The stakeholders expressed needs for a wide variety of fire science information, data, and tools. Responses reflected the importance of stakeholder engagement and science co-production to ensure the relevance of fire science products and tools. Described needs are organized into a range of categories that fit into five higher level themes (fig. 1.5), detailed below. Responses addressed needed data, tools, and products in general as well as specific research priority areas and perceived needs for greater research accessibility and stakeholder engagement.

\section{Data Needs, Tools, and Products}

Reflecting the USGS's well-known expertise, many stakeholders mentioned aspects of remote sensing, geographic information systems (GISs), spatial data, and mapping as important areas of focus for the USGS. Numerous stakeholders also described a need for research syntheses across high-level topics and summaries of individual studies in the forms of fact sheets, videos, and webinars. Stakeholders described the USGS as poised to support a variety of specific models and analyses, including landscape-level modeling and integrating fire into other models, such as for ecosystems or water. Stakeholders mentioned a need for tools and platforms that support data collection, storage, and management, as well as a need for tools and products aimed specifically at aiding decision making and evaluation.

\section{Priority Research Needs}

Stakeholders identified a variety of specific topics of study that are important to them and their organizations and that they perceive the USGS is positioned to meet. The most frequently noted needs were research related to fire behavior, post-fire effects, and the role of post-fire restoration and rehabilitation. Next most frequent were needs related to fire risk, mitigation of risk, and relationships with other natural hazards, such as drought's influence on fire risk and fire's influence on landslide and debris-flow risks. Other noted needs related to watershed and water quality impacts, smoke and air quality, fuels management and fire ecology, fire history and climate, and fire management and decision support.

USGS organization and operations

Funding, cost, resources

Lack of information, awareness, outreach

Lack of actionable science

Ego, personality, attitudes

Data ownership, privacy

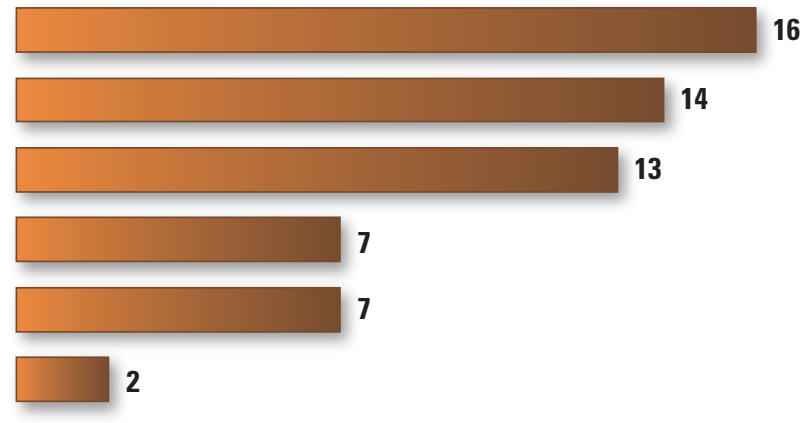

Figure 1.4. Number of times stakeholders mentioned specific impediments to working collaboratively with the U.S. Geological Survey. 


\section{Accessibility and Interpretation}

Consistent with results in other topic areas, many stakeholders mentioned a need for greater communication about USGS fire science and the availability of the science, tools, and data, including more comprehensive and concise mechanisms for learning about USGS fire science. As one stakeholder mentioned, "anything USGS is developing we need to know about and serve it to the public..." and in the words of another, "managers need help to communicate fire science to local public." Relatedly, stakeholders also mention a need for greater access to science, data, and tools, including access to peer-reviewed publications and also the development and support of accessible science databases.

\section{Stakeholder Engagement}

Reflecting a general consistency among the stakeholder discussions, many stakeholders expressed a need for greater communication, collaboration, and coordination across agencies, organizations, and different stakeholders including managers, policymakers, and the public. Individual comments indicated a need for co-production between managers and research scientists as well as an embracing of cross-boundary management opportunities.

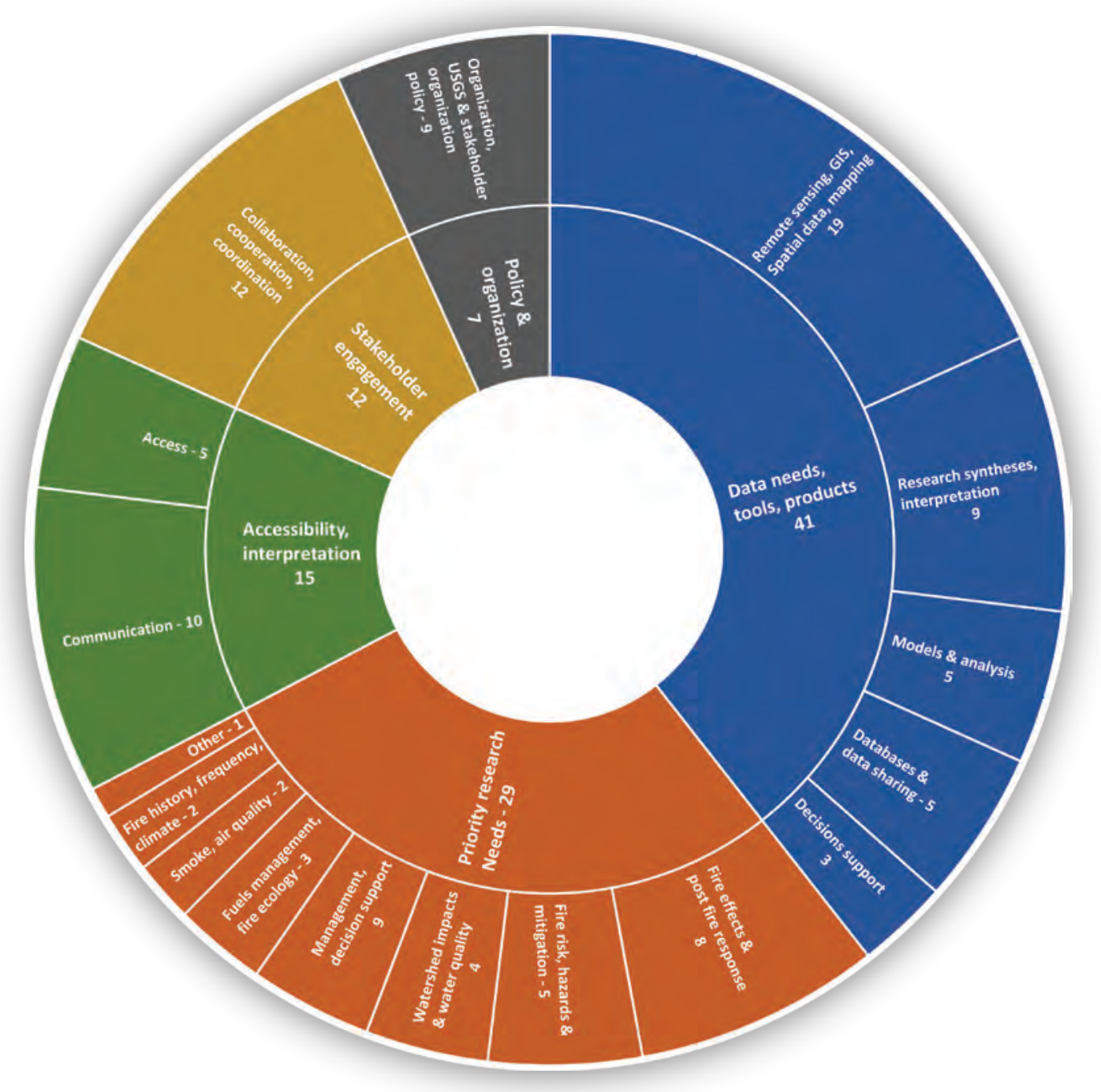

Figure 1.5. Number of times stakeholders mentioned specific fire science needs that the U.S. Geological Survey can meet in the future (outer ring), organized into five broader themes (inner ring). 


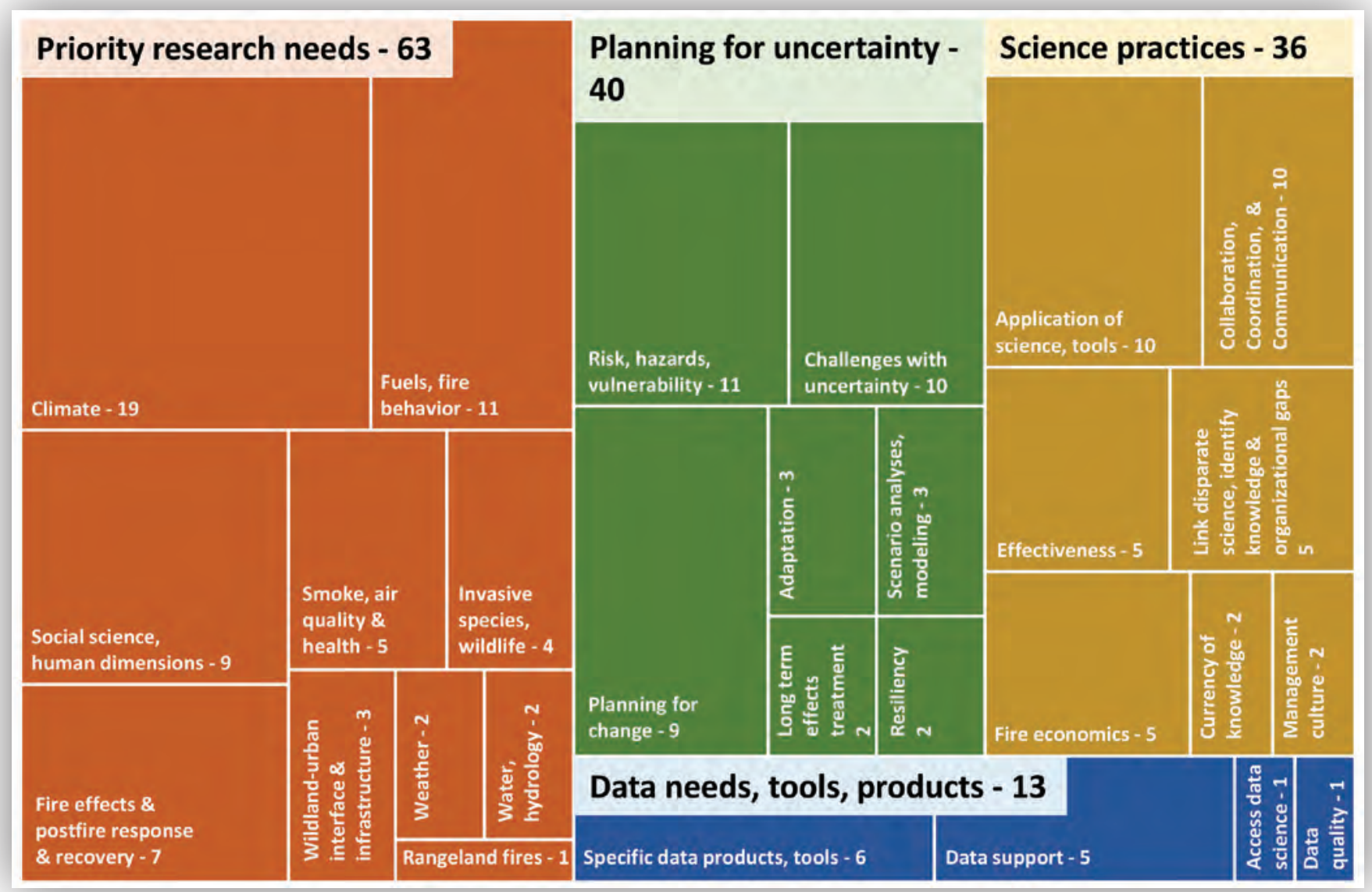

Figure 1.6. Number of times stakeholders identified specific, key science needs for fire managers in the next 2 to 10 years and beyond. Science needs are organized into four higher level themes.

\section{Policy and Organizations}

Stakeholders shared opinions related to the operations, policy, procedures, and costs associated with USGS and stakeholder organizations. For example, stakeholders recognize the "challenge across all land management agencies [of] not enough money-especially for fire." Others emphasized the importance of recognizing differences in social and geographical context across regions of the country. Still others noted the potential for USGS science to inform their need for social license in land and fire management decisions.

\section{Future Fire Science Needs}

The final topic area addressed science needs not necessarily in the context of USGS's identified strengths and capabilities but more generally in terms of fire managers' needs. Stakeholder responses were again highly variable; however, four higher level themes emerged: priority research needs; planning for uncertainty; science practices; and data needs, tools, and products (fig. 1.6).

\section{Priority Research Needs}

As expressed by one-half of the stakeholders, a dominant, priority research topic relates to climate change and reflects the fundamental challenges of anticipating and addressing climate change impacts, including how to manage fires in this context. Mirroring responses to the USGS-specific topic described above, many stakeholders also perceive the ongoing importance of continued research on fuels, fire behavior, and fuels management before and during fires. Other pressing needs include an interest in fire effects and post-fire response and recovery; smoke, air quality, and health; and water resources and hydrology. 
In addition, many stakeholders identified a need for more fire-related social sciences research, research focused on human dimensions, and better understanding of how social factors relate to or influence wildfire management, effects, and risk. Relatedly, some stakeholders noted the importance of focusing on infrastructure and the combination of structural and wildland fire that characterizes fires in the wildlandurban interface. Other topics of importance include wildlife communities and invasive species management, including managing cheatgrass (a fire-adapted, invasive annual grass), and the need to understand wildlife communities beyond a focus on high-profile species such as sage grouse.

\section{Planning for Uncertainty}

Discussions also conveyed substantial science needs related to planning for uncertainty. Many stakeholders describe a pressing need to better understand fire-related risk, hazards, vulnerability, and the intersections and management thereof. Specific needs mentioned include "defensible, national-scale approaches for risk assessment," a "focus on interacting hazards," and greater consideration of vulnerability. Stakeholders also frequently expressed a challenge in planning for change; as one stakeholder commented, "how will my landscapes change, so I can prepare for that versus managing what is already here, how I always have?" In addition, many stakeholders also expressed a concern regarding the "daunting" challenges that arise from facing an uncertain future, including changes in management practices, uncertainty in "new normal" regarding fire behavior, and biogeographical changes. Other areas of need related to planning for uncertainty include scenario analysis and modeling, managing for resiliency, embracing adaptive management, and developing better understanding of long-term strategies and effects.

\section{Science Practices}

Stakeholder discussions conveyed a pressing need for continued improvement in science practices in general. A frequent concern noted is a need to not only improve decision making with tools but also to place great emphasis on products, outcomes, and the importance of crafting research to meet an applied need. Relatedly, many stakeholders noted a need for greater collaboration, coordination, and communication across contexts and parties, including across agencies, jurisdictions, stakeholders, and geographic areas. Discussions describe a need for greater linkage, synthesis, and overlap of science and research across different topic areas and information sources, as well as an increased focus on economic aspects of fire management and decision making, including costs, benefits, budgeting, and economic impacts.

\section{Data Needs, Tools, and Products}

Some stakeholders reiterated a pressing need for specific data products and tools for certain applications, such as new databases on fire occurrences, improved capabilities for physics-based fire modeling, and increased recognition of the importance of unmanned aerial systems (UAS) for fire support. Relatedly, some stakeholders mentioned a need for continued support of specific data products, information technology support, and data continuity, such as for highprofile products such as LANDFIRE and MTBS. Finally, stakeholders specifically mentioned the importance of maintaining quality assurance for public-facing data and of providing transparent pathways for accessing data, science, and information.

\section{Conclusions}

We identified and incorporated the stakeholders' perspectives, information needs, and potential improvements critical for strengthening USGS fire science research and engagement into one or more of the four integrated priorities that form the basis for the USGS Wildland Fire Science Strategic Plan. These data provided valuable affirmation of relevant information and were used to help solidify priorities defined in the Strategic Plan. 


\section{Summary of information acquired from stakeholders and its relevance to the U.S. Geological Survey (USGS) Wildland Fire Strategic Plan priorities.}

\section{Topics discussed by stakeholders}

Learning about USGS fire science

\section{Direct relevance to USGS Wildland Fire Strategic Plan priorities}

Personal relationships and interactions between stakeholders and USGS scientists and fire science leadership were identified as the predominant method by which stakeholders learn about new fire science. In addition, numerous stakeholders mentioned a reliance on general internet searches to identify current science, data, and tools relevant to their work.

These collaboration and communication pathways highlight the importance of engaging stakeholders in science production (priority 2) and communication of USGS fire science capacity, products, and information (priority 3).

Familiarity with USGS fire science

A relatively small proportion of stakeholder discussants conveyed that they were familiar with USGS fire science. In some cases, stakeholders were primarily familiar with work performed by individual scientists yet possessed little familiarity with the broader, USGS-wide capacity. Many responses indicated the need for greater communication about current USGS fire science, tools, and data, including more comprehensive and concise mechanisms for learning about USGS fire science.

This highlights the importance of engaging stakeholders in science production (priority 2) and communicating USGS fire science capacity, products, and information (priority 3).

Impediments to stakeholder engagement Perceived impediments to stakeholder engagement and collaboration with USGS on fire science and collaboration with USGS on fire science exist. Although a primary concern expressed among stakeholders was the funding costs of co-producing science, they also described a lack of information about USGS fire science as a barrier to collaboration.

Responses highlighted a need for greater communication, collaboration, and coordination across agencies, organizations, and different stakeholders including managers, policymakers, and the public. Priorities 2 and 3 of the Strategic Plan describe enhancements to stakeholder engagement, communication, and outreach intended to identify and address these issues.

Stakeholder needs targeted to the USGS

Stakeholders expressed needs for a wide variety of fire science information, data, and tools. Those identified as being within the USGS capacity include delivery of remote sensing, geographic information system, spatial data, and mapping products; science syntheses and science briefs; landscape-scale models integrating fire with ecosystem and hydrologic processes; and tools and products aimed specifically at aiding decision making and evaluation.

Identified research priorities included science related to fire ecology and behavior, postfire effects, and post-fire restoration and rehabilitation; fire risk, mitigation of risk, and relationships of fire to other natural hazards such as drought and debris flows; and fire impacts on air and water quality.

Priority 1 of the Strategic Plan describes how the USGS is committed to continuing support for core science production and development of tools and decision-support products.

Future fire science needs not necessarily within current USGS capacity but critical to inform fire management
Future, pressing fire science needs not necessarily within current USGS capacity but critical to inform fire management in the coming decades were identified during the discussion process. The most important of these (by frequency of responses) reflects the need for science that addresses the fundamental challenge of anticipating and addressing the impacts of climate change and changes in fire behavior and fire effects. Fire science needs related to planning for uncertainty were highlighted, including a pressing need to better understand changing or future risk, hazards, and vulnerabilities for social and natural systems. Other important research needs included expanded research on fire ecology, fire behavior, and fuel dynamics and management as well as the need for more fire-related social science research, research focused on human dimensions, and better understanding of how social factors relate to or influence wildfire management, effects, and risk.

Priority 1 of the Strategic Plan emphasizes production of 21 st century science to address these critical science directions. 


\section{Reference Cited}

Welsh, E., 2002, Dealing with data-Using NVivo in the qualitative data analysis process: Forum Qualitative Social Research, v. 3, no. 2, article 26.

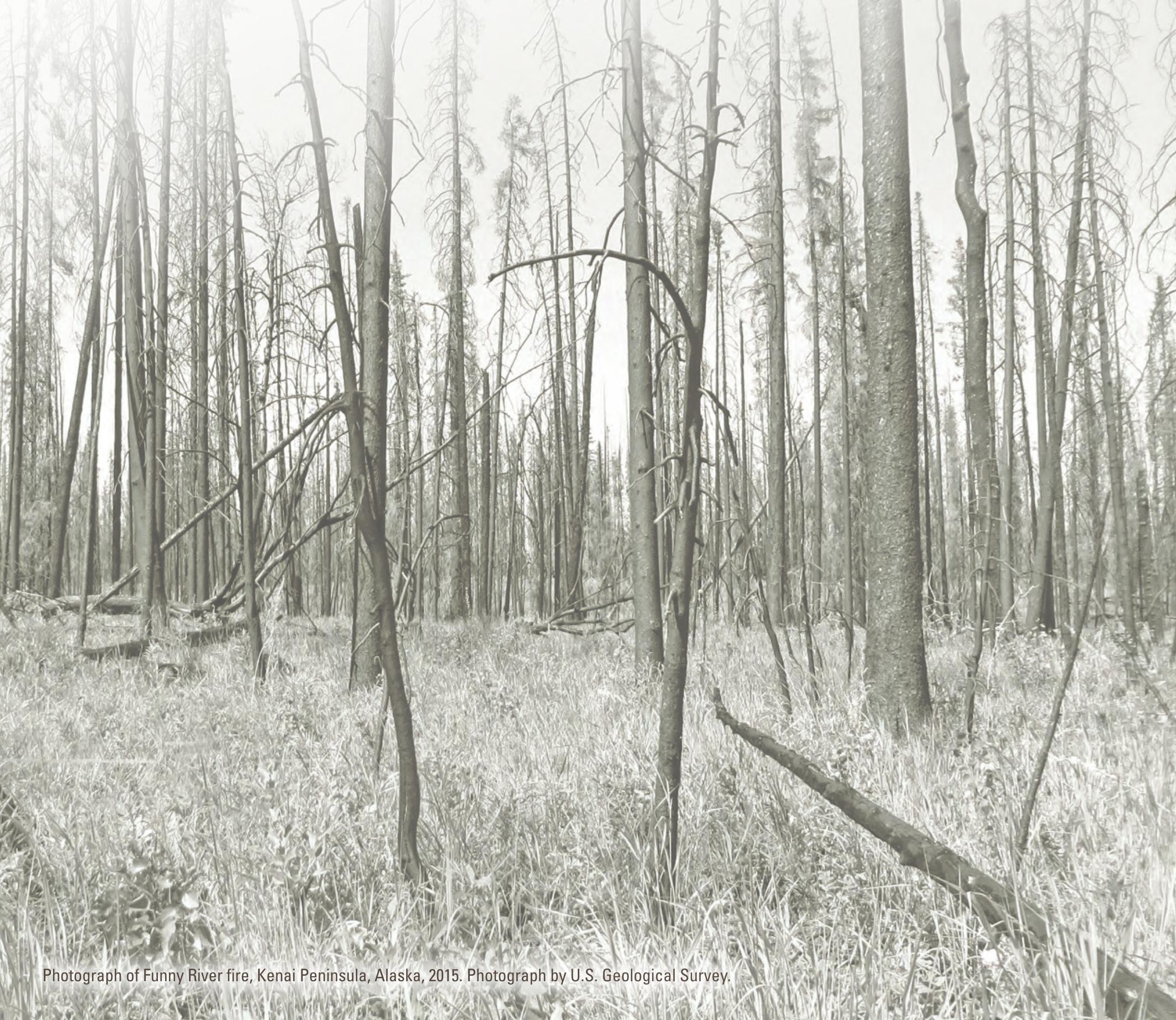


For additional information, contact:

Associate Director

Ecosystems Mission Area

U.S. Geological Survey

Mail Stop 300

12201 Sunrise Valley Drive

Reston, VA 20192

Publishing support provided by the U.S

Geological Survey, Science Publishing Network, Reston and Tacoma Publishing Service Centers.

Design: William Gibbs 
